$(826)$

\title{
こりぱのぞーまノ生體染色二關スル研究 (I)
}

\section{第 1 編，序高並二生體染色陽性色素八檢索}

宗都需國大學㗨學部微生物學敉室（主任 木村教授）

\author{
醫樂士 奧 川 $川$ 三
}

本論文つ要泞八炤和 8 年 4 月第7回聯合微生物學會=於テ演述セリ.

\section{【内 容 抄 錄】}

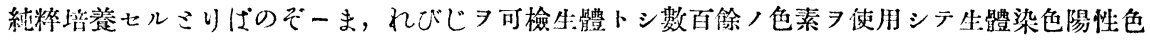
素ノ檢索习試ミ生骹染色陽性色素, 1 群习檢出シ得タリ. 份之二關聯シテ色素ノ理學的性狀, 各 種可檢生體/檢索成紸卜/比較, 親和力, 生體=及ボス影響並二色素加培地上, 生體/發有狀况 等二關シ研究セり.

序言

第 1 章 實驗方法

第 1 節 低試材料

第 1 項 偕武きりぱのぞーま

籍 2 项 供試色素
目次

第 2 節 苗驗㙅作及檢索方法

第 2 章 實驗成績

第 3 章 總括並二考察

結 諭

\section{序言}

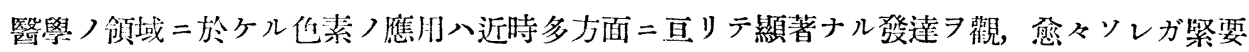
性ヨ加フルニ至レリ.

生體染色二關シテ本學清野敉授並二門下生等ガ廣汎且ツ精密ナル 系統的研究業續 テョリ該方面ノ研究入頓二異常ノ進展ヨ觀ツツアリ, 從來微生物學方面二於ヶル生體染任,

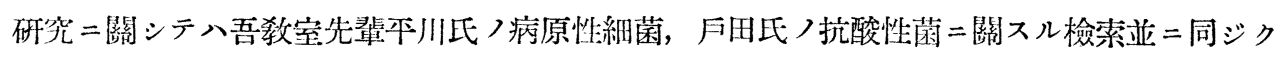

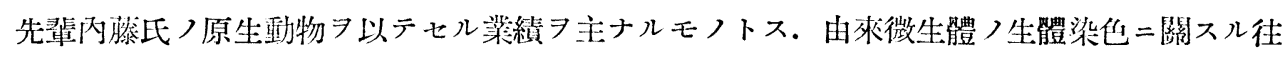
年ノ業績八多ク八單純ナル载物确子板上ノ檢索ヨ以テ滿足七ルモノニシテ，單二可檢生體 凹素液二混和シ觀察シ得タル二過ギズ，然モソ八極ク少數つ出素種類习使用シ簡易ナル 2,3 ,

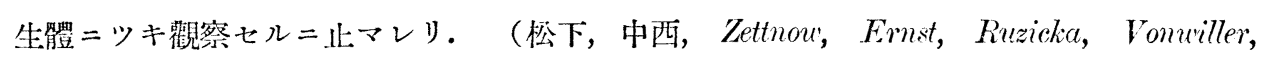
Giemsa, Vay 參澋).

然ル二吾敉空二於ケル叙上つ請先輩八可及的多數つ色素種類ニテ生體染色

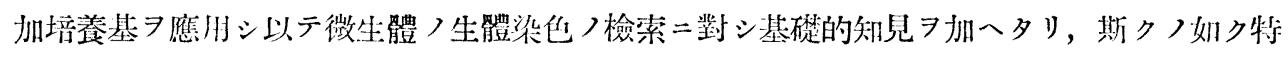

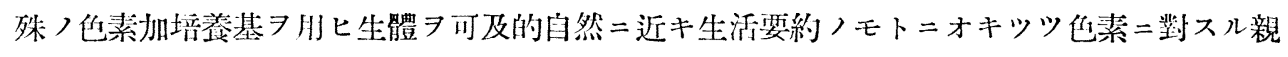

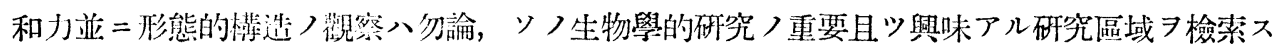




$$
\text { 奧 川 } \quad \text { 川 述 }
$$

ルヨ得バ殆ンド理想的ナリ，從ツテソノ成果モ大イ=期街スベキモノアラン.

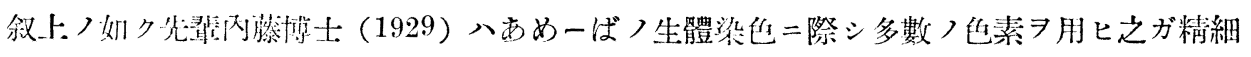

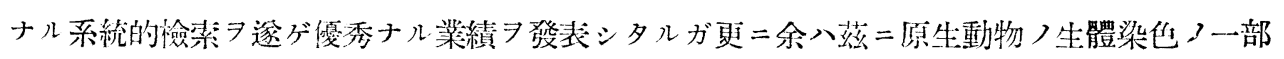
阿トシテ純培養ノよりばのぞーま，れびじ(Trypanosoma Lewisi) ヨ胕ヒ之ガ生體染色二關 スル㸴究ノ步习進メタリ。

抑々醫學二筑聯ヨ有ス儿原生動物ノ中純培養可能ト七ラルルモノ八あめーば，とりぱのぞ

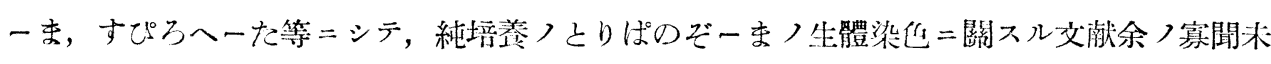
ダ之レアルョ知ラズ，而シテ內藤博士ノあめー壮ノ生體染秹二於テモ可檢生體八嚴密ナル純 培養ニヨルモノニアラズシテ其ノ共㜀細菌ヨ混ゼリ。ヨツテ原生動物二關スル限リ純培食ノ

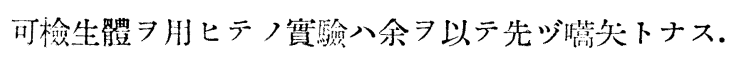

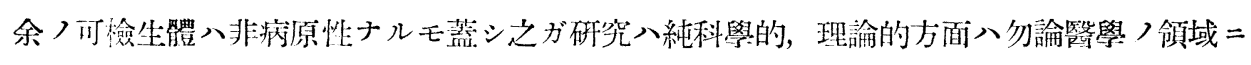
於テ八特二病原性资料 >研究二對ス儿對照的意義 アラン.之余ガ該研究ヨナセシ所以ノモノニシテ敢テ徒爾ナラズト信ズ.

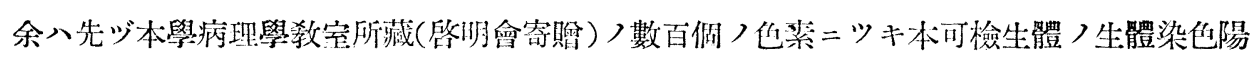

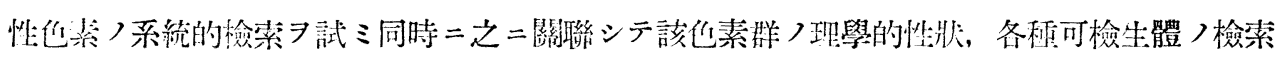

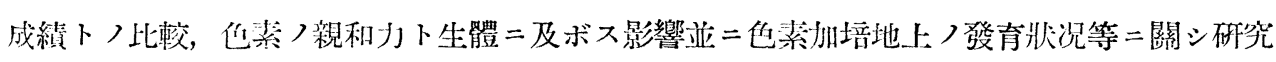

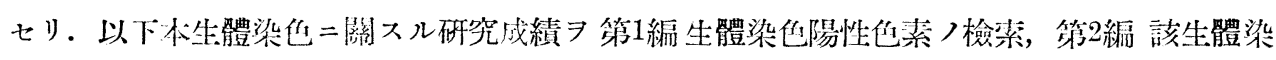
〔陽性〔䒺つ理學的性状，各種可檢生體ノ成績卜ノ比較，第3編仙素つ生體二及ボス影響並

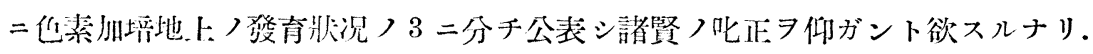

\section{生體染色陽性色素, 檢䇣}

從來生體染色像ヘソノ生命保持)程度ニョリ生體染色（vitale Färbung）超生體染色 (supravitale Färbung) 及死後染色 (postvitale Färbung) =大別七ラル. 死後染色卜生體染色卜）

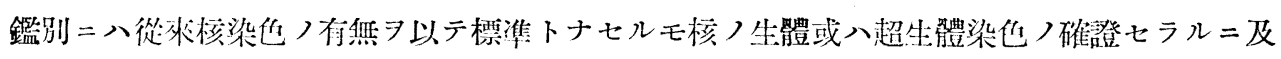

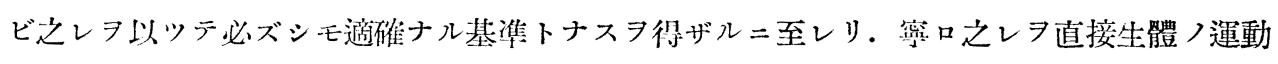
或八形態的變調ニョリテ判定シ得ルニ若カズ, （杉山，洞野，Houge）生活機能〉觀察容易 ナラザル組織細胞二關ス几檢菜つ如キ二於テハ染色像ヨ以上ノ 3 者ニ分ツコト必ズシモ容易 ナラザルモノニシテ杉山博士ガ「便宜上一般操作上ニ於ケル相違二據り之レヨ 3 者二分ツベ シ」トナセルモ亦宜ナリ。

要之現時八叙上ノ 3 者八劃然卜分千得べキモノニアラズト見做サル, 即千生體染色卜超生 體染色卜ハ本管的ニハ同一ノモノナルベシトナシ更二死後染色 
つ關聯习有ストナシ (杉川) 又核染色二於テモ亦生體並二死後染色ノ爾者八連續的ノモノナ リト解七ラル。（岡野）

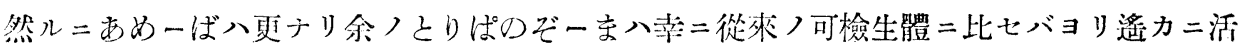
潑ナ儿固有運動 ヨ存シ生活状况つ變化

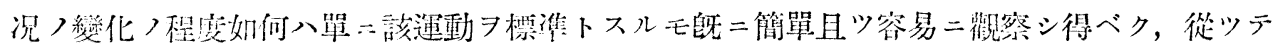

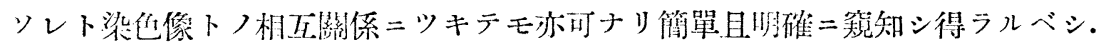

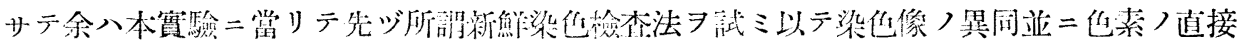

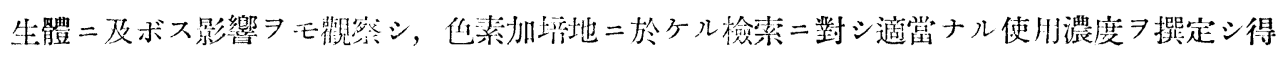

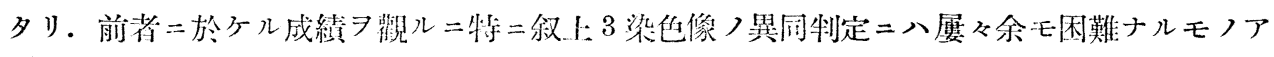
ルヨ識リタルモノニシテとりぱのぞー亦平時ニ於テ活潑ナル固有運動ヨ示スト雖モ他方二

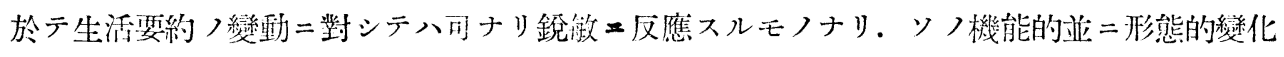
モ亦微妙且ツ複雜ナルモノアリ，從ツテ之レガ生活状况习屡及簡略二叙上ノ 3 期ニ分ツコト

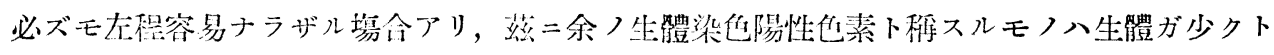

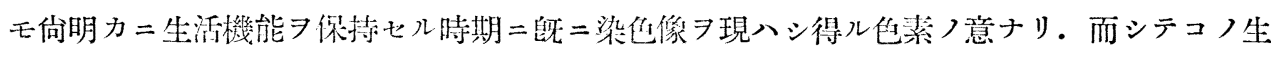

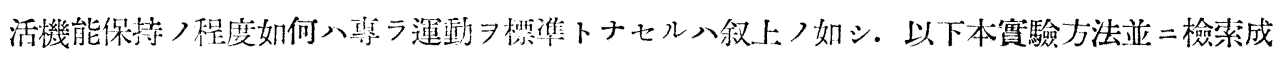
績习記述スベシ.

\section{第 | 章䨢 驗 方 法}

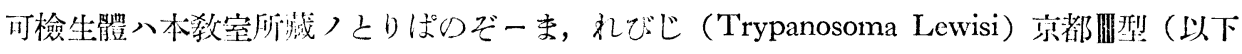

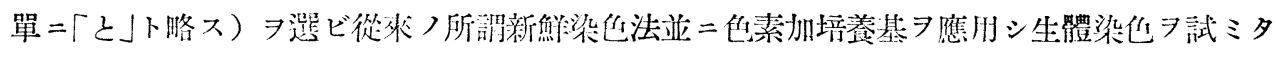

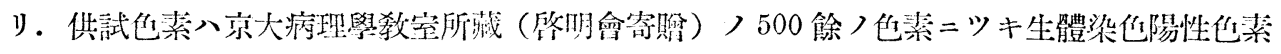

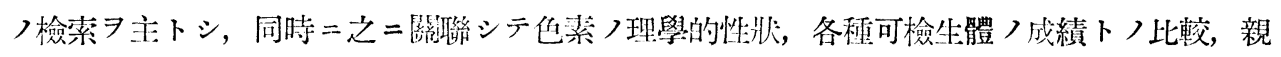
和力, 生體=及ボス影響並二色采加培地上つ生體發育状况等=關シ實驗研究セリ。賽驗的操 作及觀察方法卜ノ2笁二分チ之ガ概括的記述アナスベシ.

\section{第 I 節 供 試 材 料 \\ 第 1 項 供試「と」二就テ}

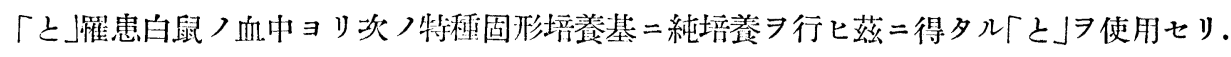
(植田秀嶺諭文參照).

培養基八 Bouillon = Orysanin 1\%, Pepton (Witte) 1\%, Glucose (Merk) 1\%, Chlorcalcium (Merk) $0.55 \%$ ，寒天 $2 \%$ >制 $=$ 加へ $\mathrm{pH}$ ヲ 7.2 トシ， $100^{\circ} \mathrm{C} 20$ 分間宛 3 日間滅菌シ，

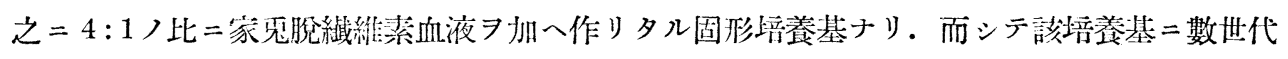
ヨ經タル「と」フ使用セリ。 


\section{第 2 項 供試色素二就テ}

供試色尖八主トシテ水溶性ノモノナレド, 難溶性ノモノ八多少加熱シ溶解习促進セシメ夕

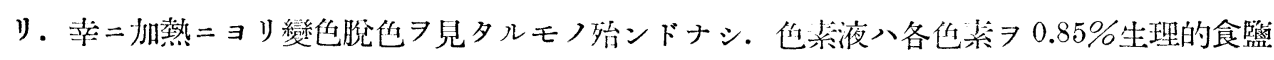

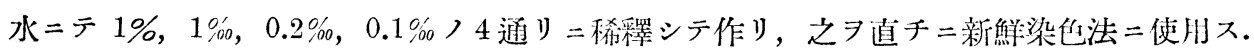

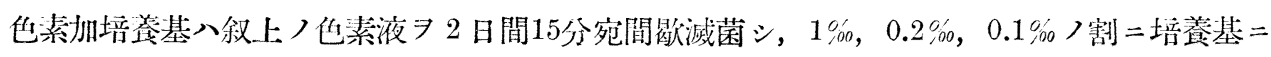

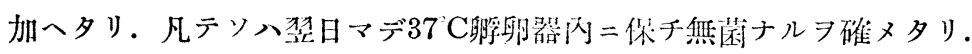

\section{第 2 節 賽驗操作及檢少方法}

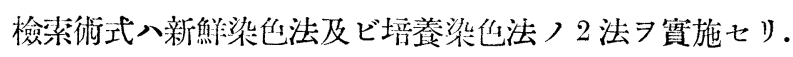

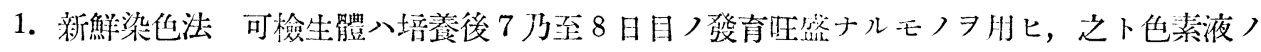

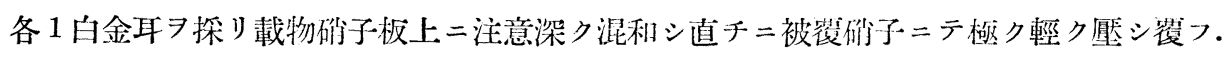

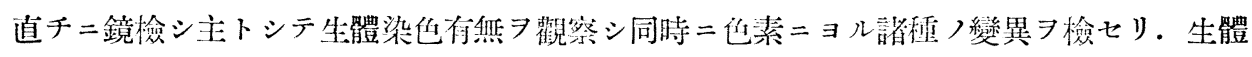

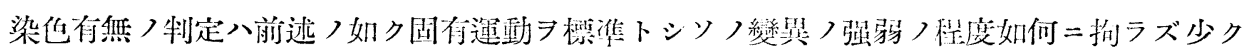

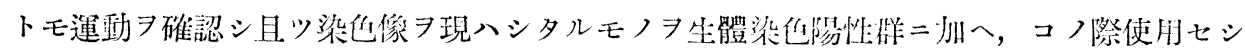
該色素ヨ生體染色陽性色素群二算入七リ。全然運動 認メザルモノト踓モ理論的二八生死

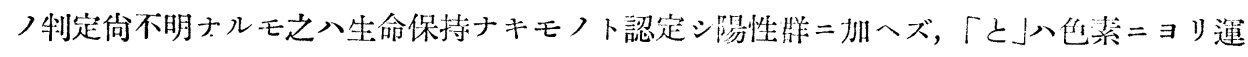

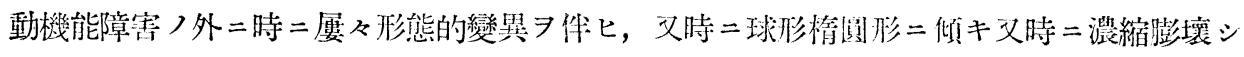

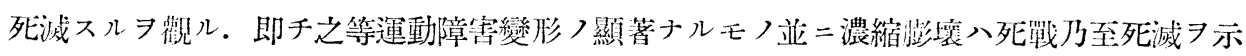

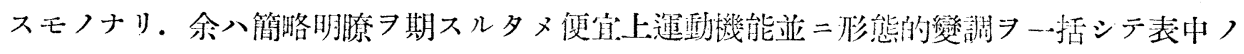
欄 $=$ 單二生體變墨卜記入七リ. 以上新鮮標本觀察入約15分以队 $=$ 於テナ七ルモノニシテー 般二純培善つと」八無處運〉新鮮標本二於テハ 15 分以內二於テハ運動並ニ形態上:著シキ變 化ヨ認メザルナリ.

2. 培養染色法 可檢生體八前法ニ於ケルト同樣ニ發育旺盛ナル「と」ノ2 白金耳ヨ色素加培

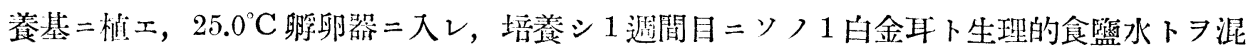

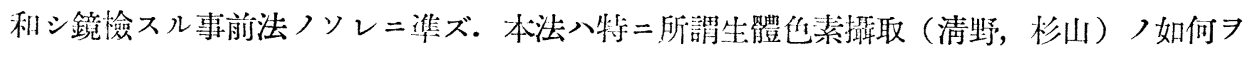
觀然七ルモノンシテ侀七テ生體つ變異习檢シ, 更二培養基上ノと」ノ聚落發育狀態, 培養

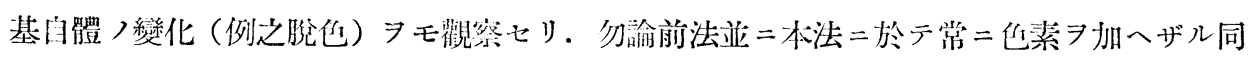
一條件ノモノラ對热ニオケリ。

\section{第 2 章 璂 驗成 績}

實驗成績习表示七バ第1，第2 及ビ第3表）如シ。(別表參照)

俏萠。

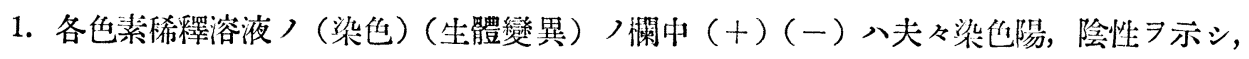


1, 2, 3 八生體變異主トシテ運動機能障害つ强弱つ程度ヨ示スモノニシテ運動八緩漫トナリ 遂二静止セントス. 1 八輕度，2 八中等度，3 八强度變異 7 意味シ，特=3 八屡々多少球 形乃至楕国形ヨナスコトアリ。特二培養成續二於テ然リ。例之 Chrysoidin A cryst. 二觀

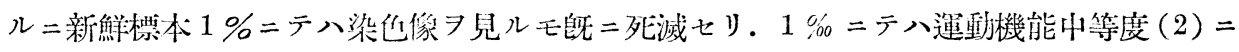
障害サレ， $0.2 \%$ ニテハ極メテ輕度 (1) 二障害サレドモ何レモ佾生命保持习認メッッ染色 像出現七リ。由ツテ該色素八コノ2 溶液つ濃度ニ於テ生體染色陽性ナリ。

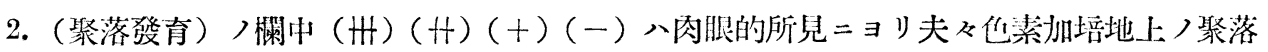
發有ノ程度习示ス.

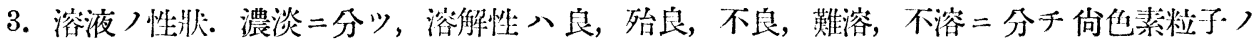

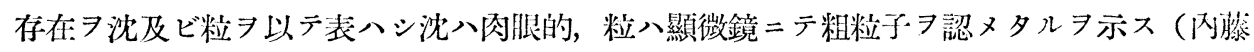
參照).

4. 任素分類 Schulz, Rowe $=ヨ$ 社名 略號八清野, 星島氏表二準ズ. $A=$ Säure f., $\mathrm{B}=$ Basische $\mathrm{f}$,

5.（あ生體染色）八閶中（十（一）八夫々內藤博士ノあめーばニ於ヶル生體染色陽性，陰 性ヨ示シ, (!!)（!）八多少留意スベキヨ示スト言ハル。參考マデニ茲ニ揭ゲタリ.

6. 第1表八新鮮染色法ニョリ「之」生體染色陽性色素群ナリ。第 2,3 表八同法ニョリ「と」生 體非染性色素群ヨ示ス. 但シ第2 表中二八培養染色法ニヨリ生體染色陽性ナルモノ少數含

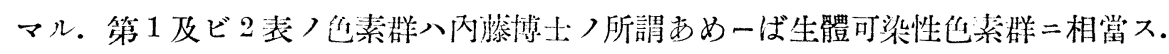

\section{第 3 章 總括並二考按}

第1 及ビ 第 2 表 $=$ 於テ新鮮並二培養染色法ニヨリ余八「と生體染色陽性色素群 (92個) ヨ得

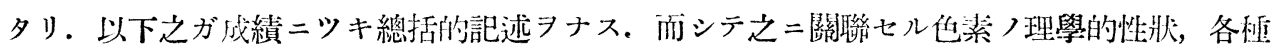

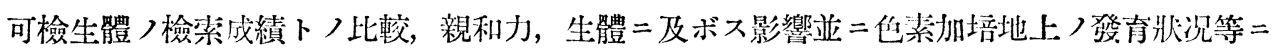
關シテハ之ガ訅述ヨ次編二讓ルベシ.

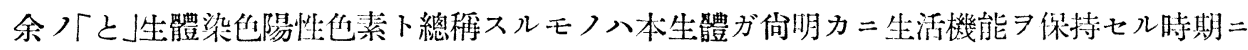
既二染色像出現习確認セルモノナレバ之等染色像中二八幾分所謂超生體染出像 フモ含ムモ， 卜思惟ス. 而シテ余八既述ノ如ク生命ノ存否如何八運動機能习標集卜七ルタメ死染卜記入セ

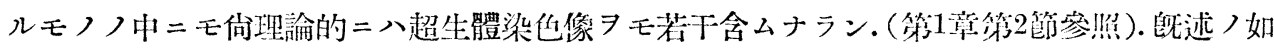

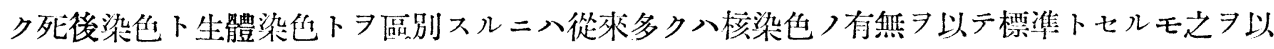

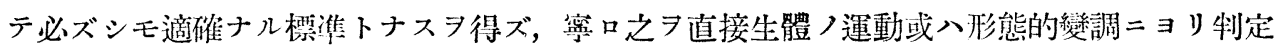
スルニ若カズトノ杉山，內藤网博士ノ所論ヨ余モ亦肯定スルモノナリ.

生活機能ノ觀察簡易ナラザル組織細胞＝關スル檢索ニ在テハ染色像フ生體，超生體，死後 
染出つ 3 者ニ分ツハ必ズシモ容易ナラザルモノニシテ從來各染色像八互二連續セル一線上二 アリト稱セラレ，杉山博土ガ「便宜上一般操作上ニ於アル相違ニ據り之ア 3 者二分ツベシ」 トナ七ル所以ナリ，肥㭌細胞，超生體染色，あめ一ばノ生體染色つ檢菜二際シ生體, 超生體

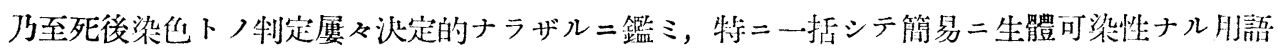

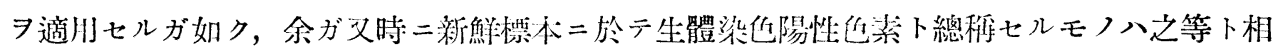
似ノ感ナキニアラズ. 余ノ本可檢生體八影二組織細胞入勿論あめ一ばョリモ活潑ナル固有運

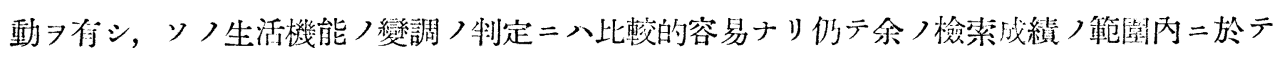

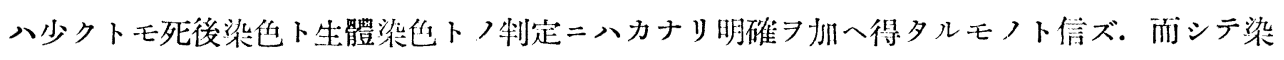
色卜運動變調ヨ來タス際二八殆ンド之等八同時二現ハルルモノノ如ク何レガ先二現ハレタル カノ制別八實際上困難ヨ感ゼリ。佾新您染色法並二培養法二於テソノ生體染色陽性ナ儿點二 於テ必ズシモ网者互二一致セザルモノ多キハソノ檢索賽施方法自體〉異闰ニヨルモノト思惟 ス.

\section{結論}

純培養ノとりぱのぞーま，れびじノ生體染色陽性色坮トシテ，可檢生體つ生命保持佮明カ

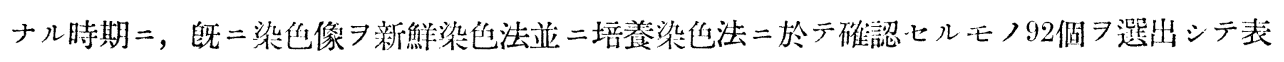
示セリ．而シテ之ア細別スレバ，新鮮染色法二於テ陽性ナルモ>87㨐，培養染色法二於テ 18 個，兩者其通二陵性ナルモノ13個，培養染色法二於テノミ陽性ナルモノ 5 佔ナリ。

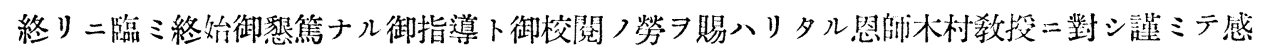
謝 つ意习表ス。

佾御助言习賜ハリタル內藤前助敉授二感謝ス.

(文 献 後 出) 


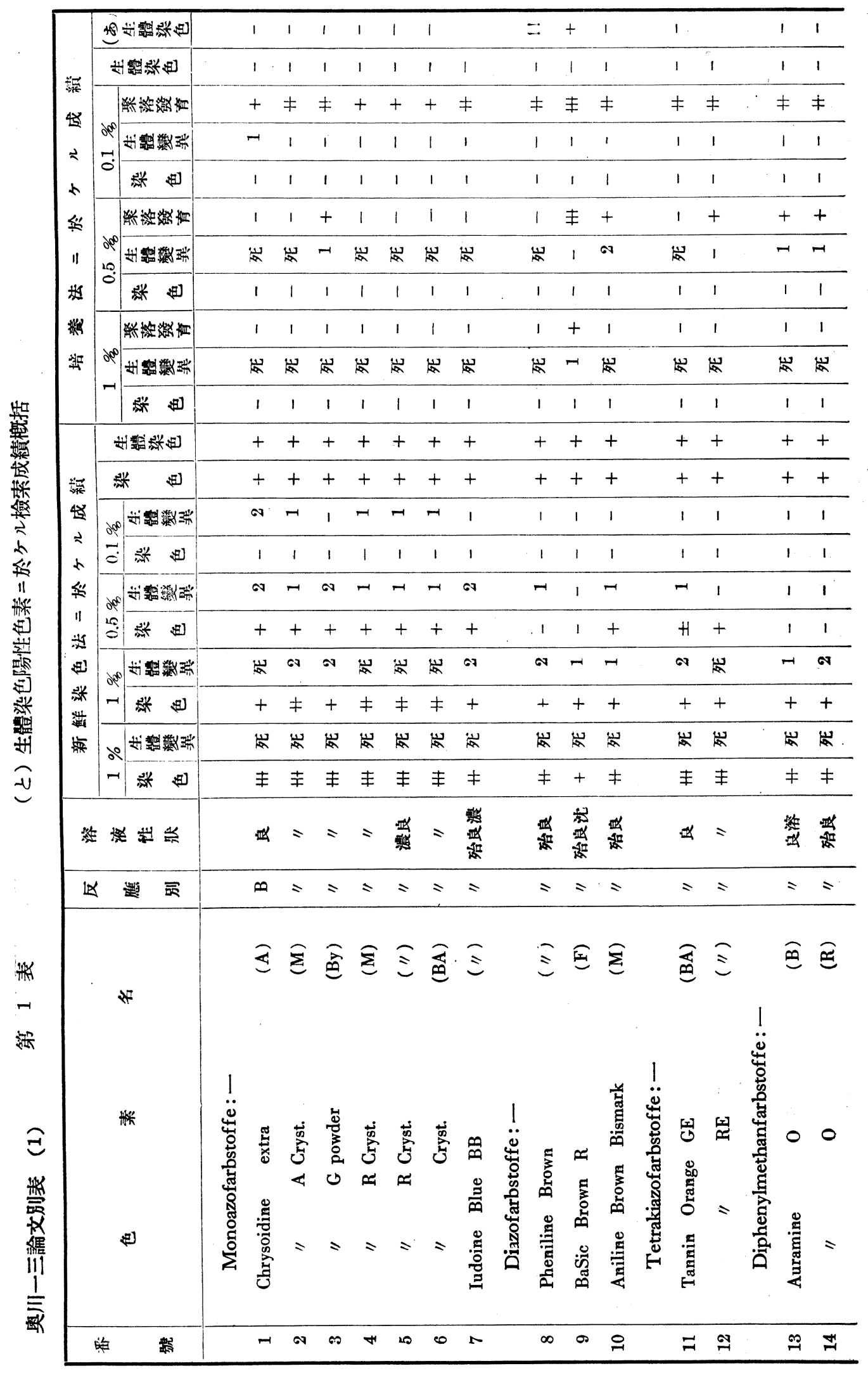




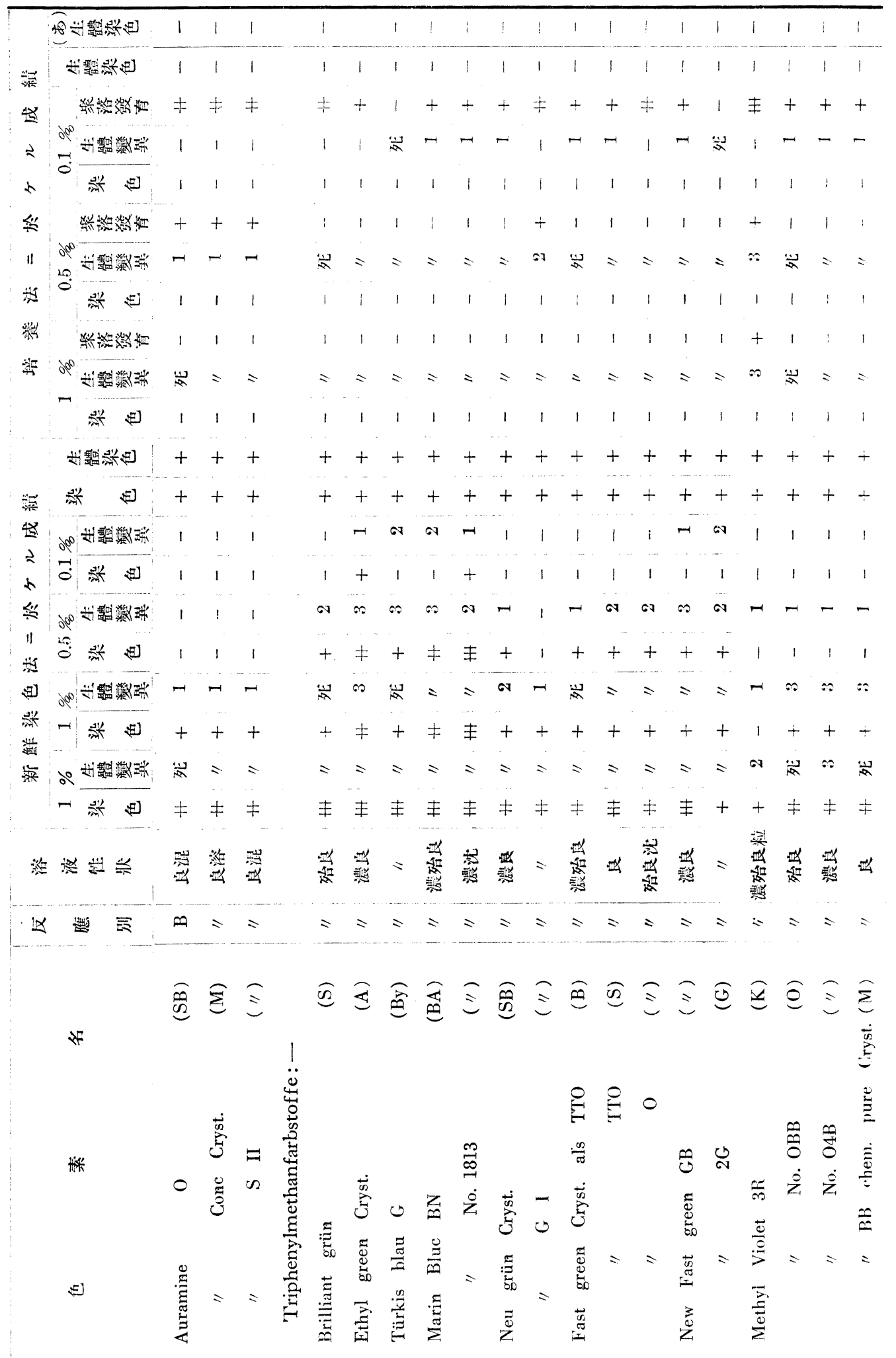

物䎏 


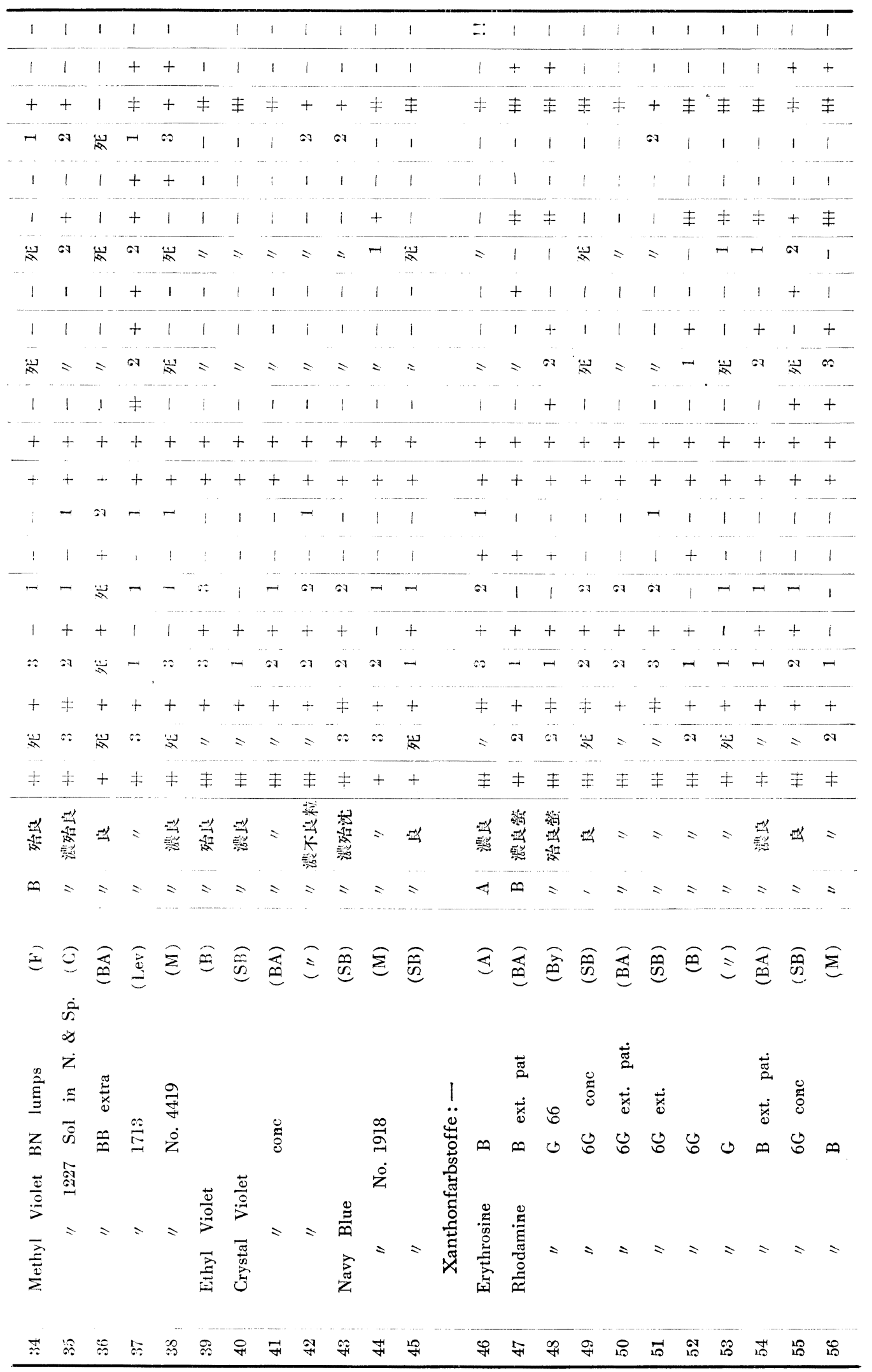




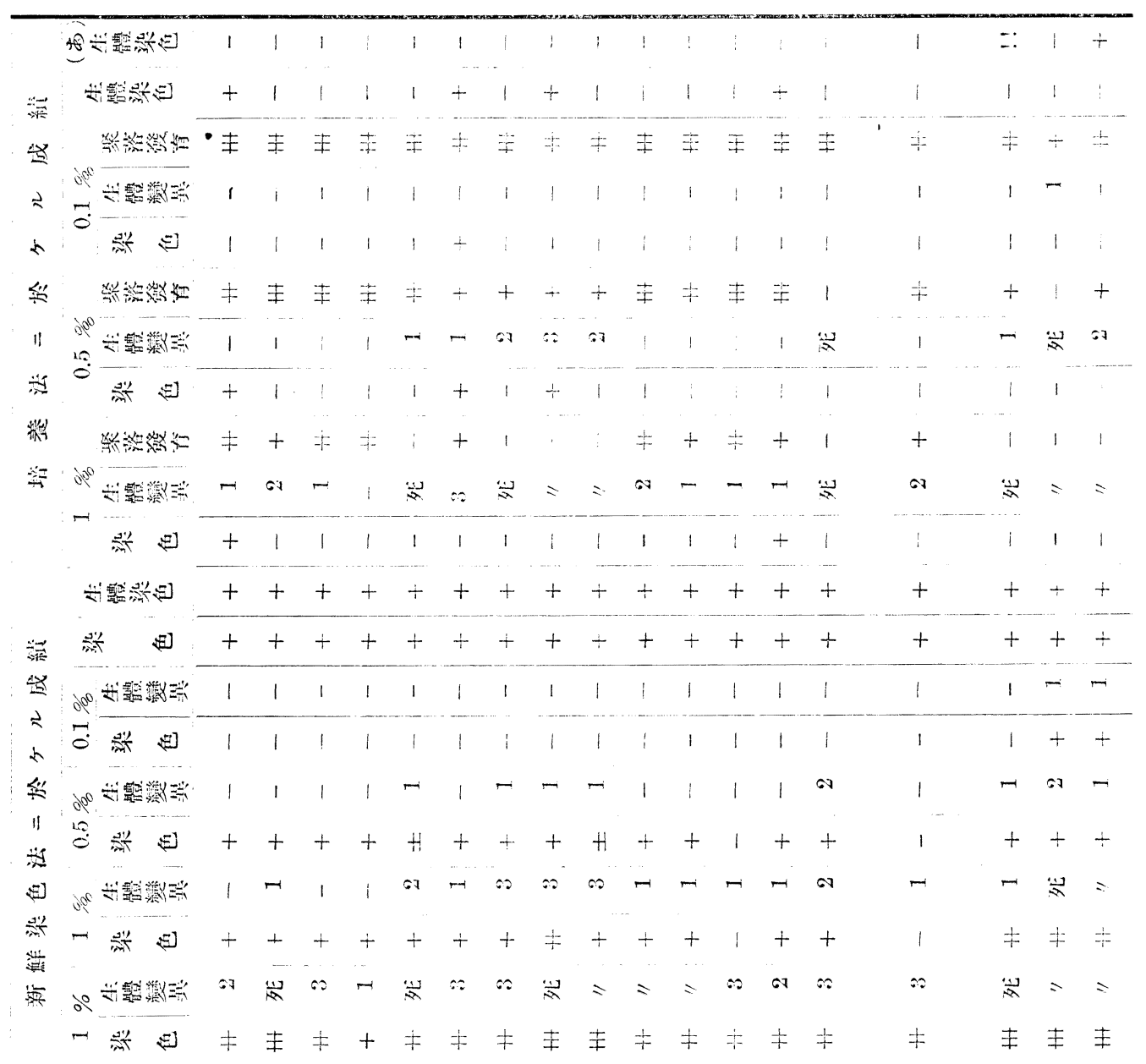

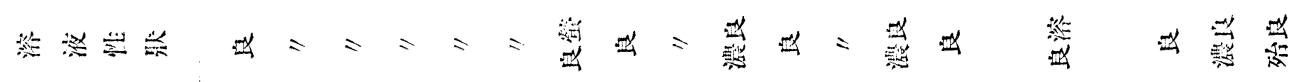

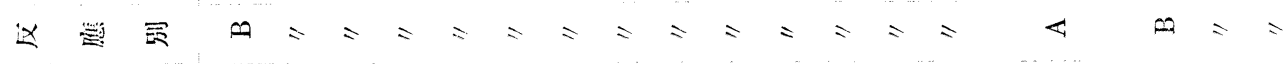

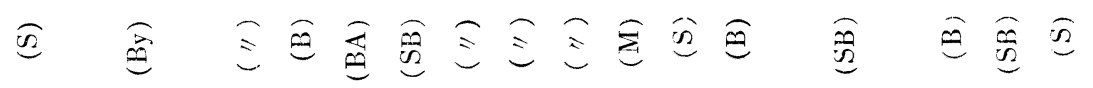

4

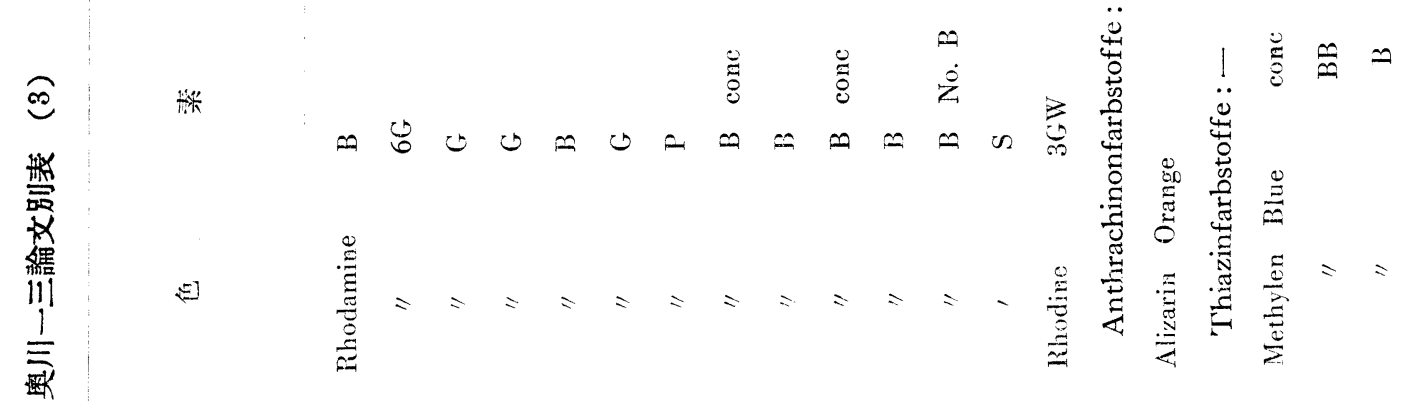

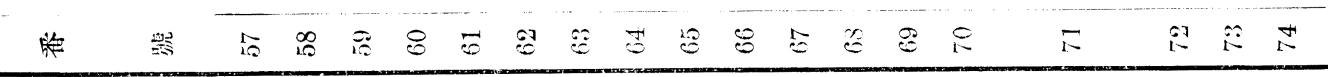




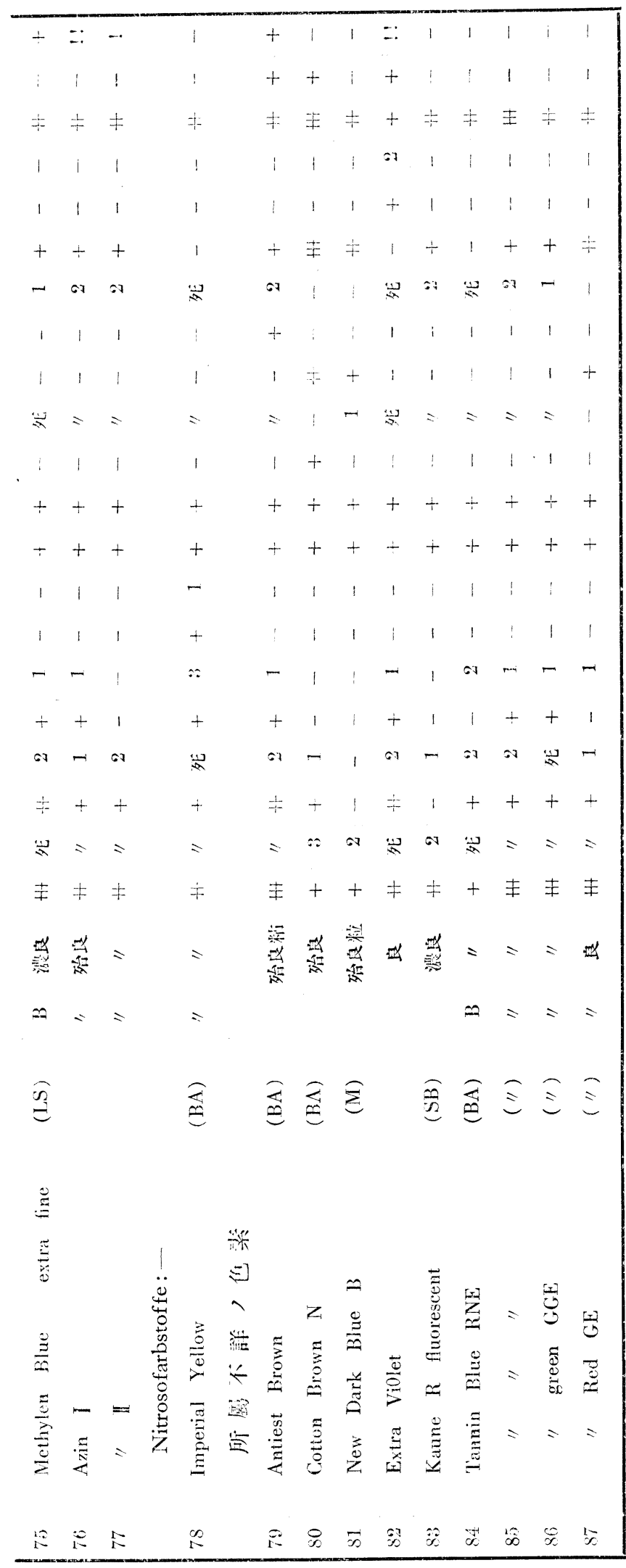




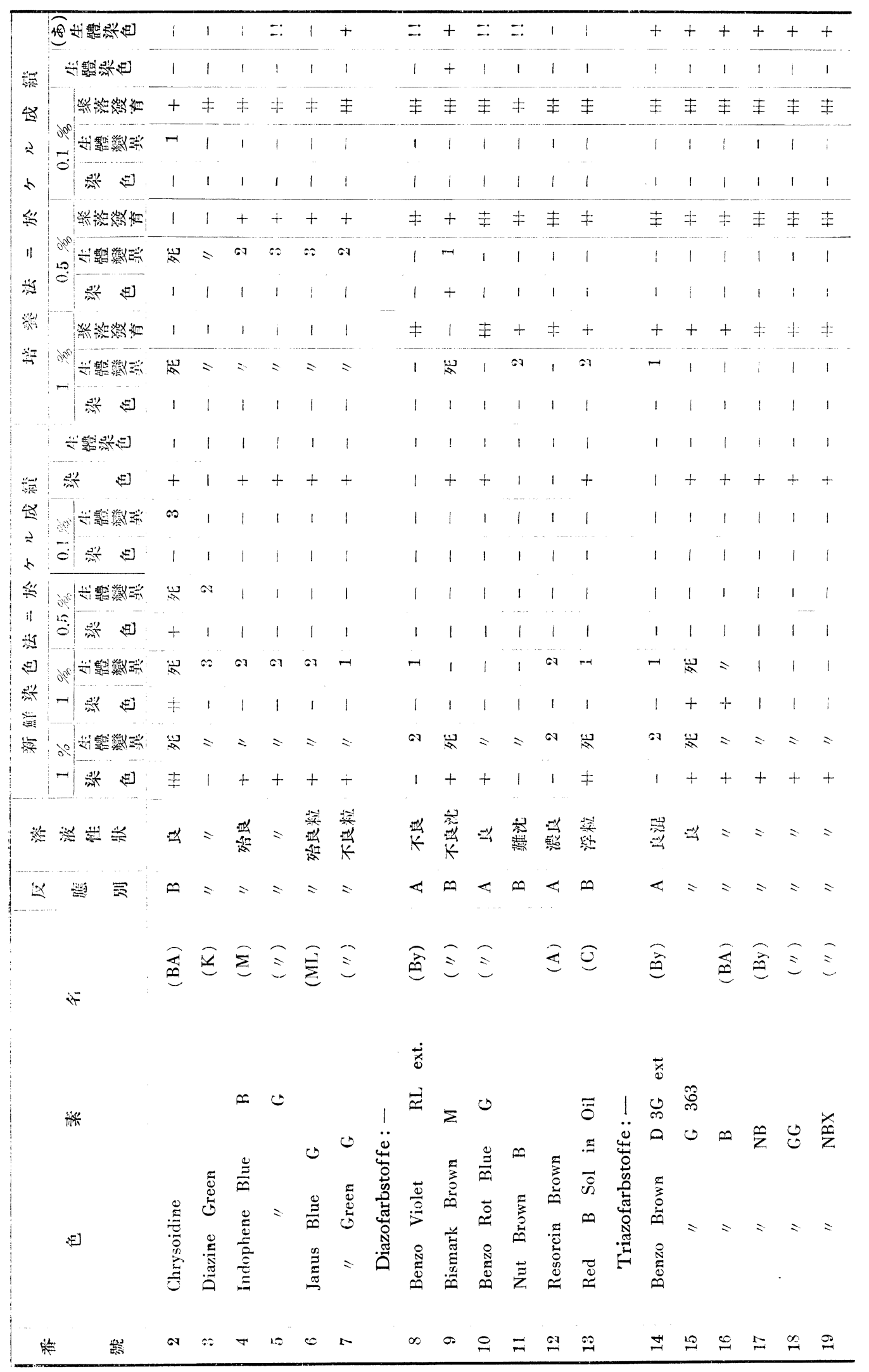




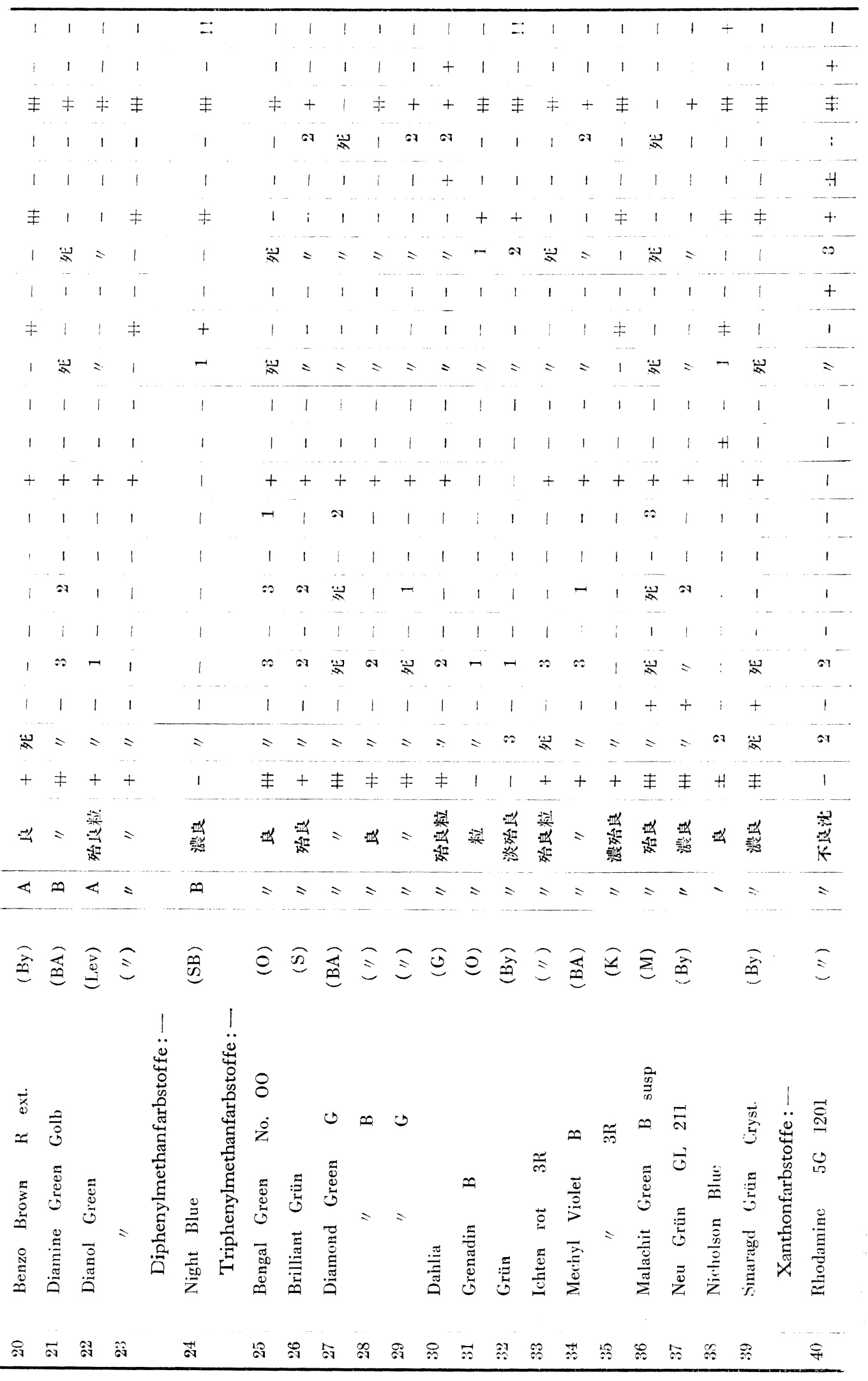




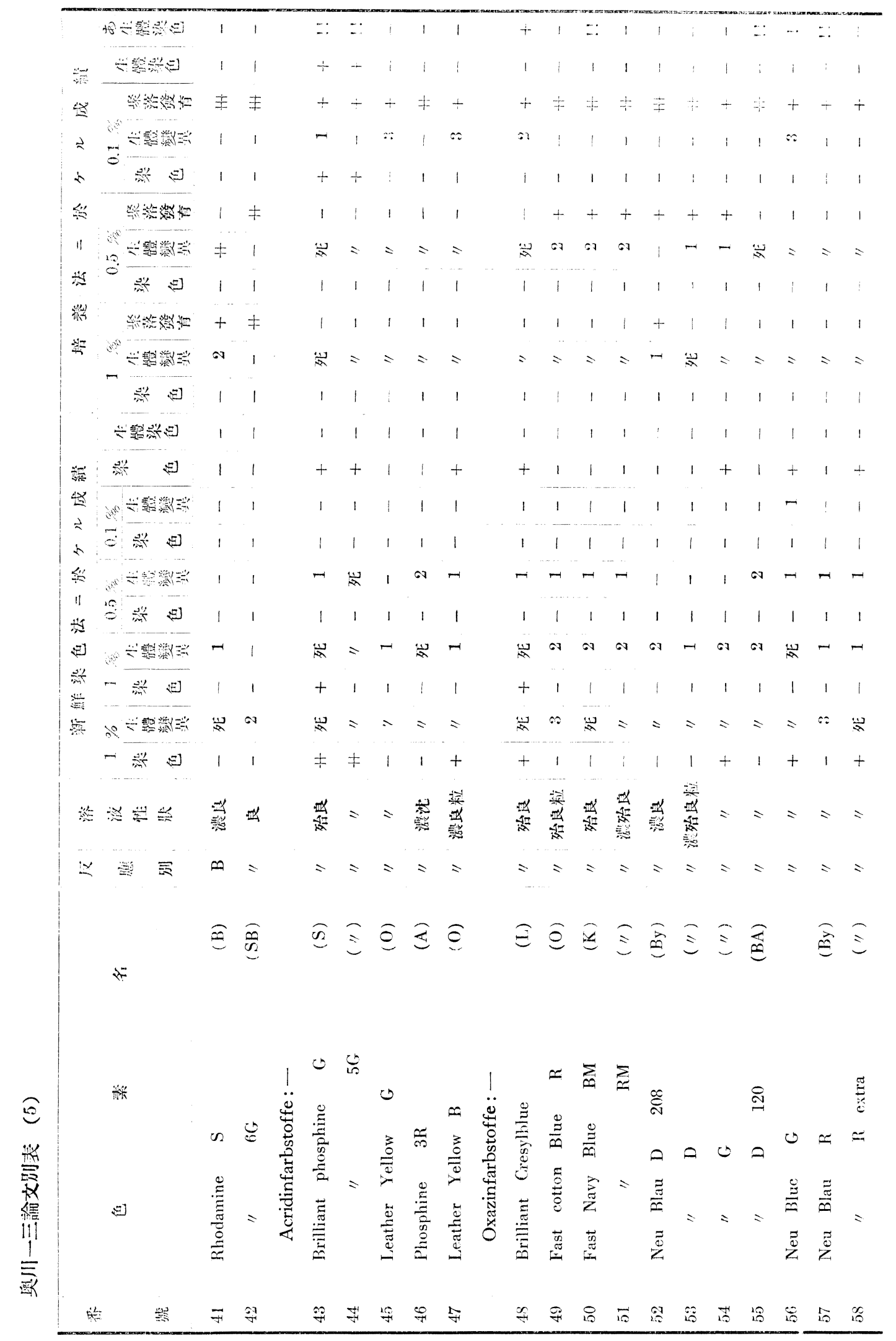




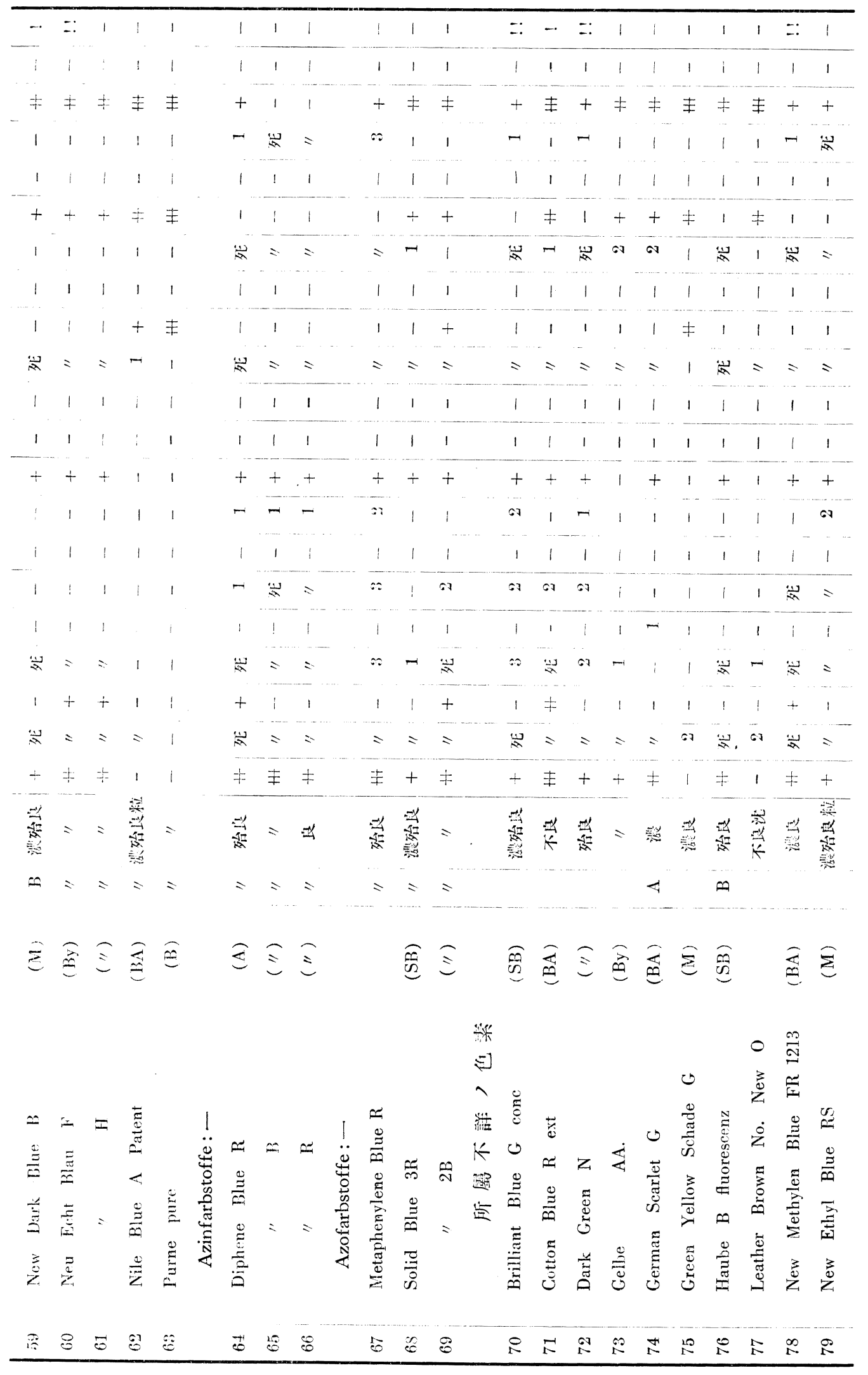



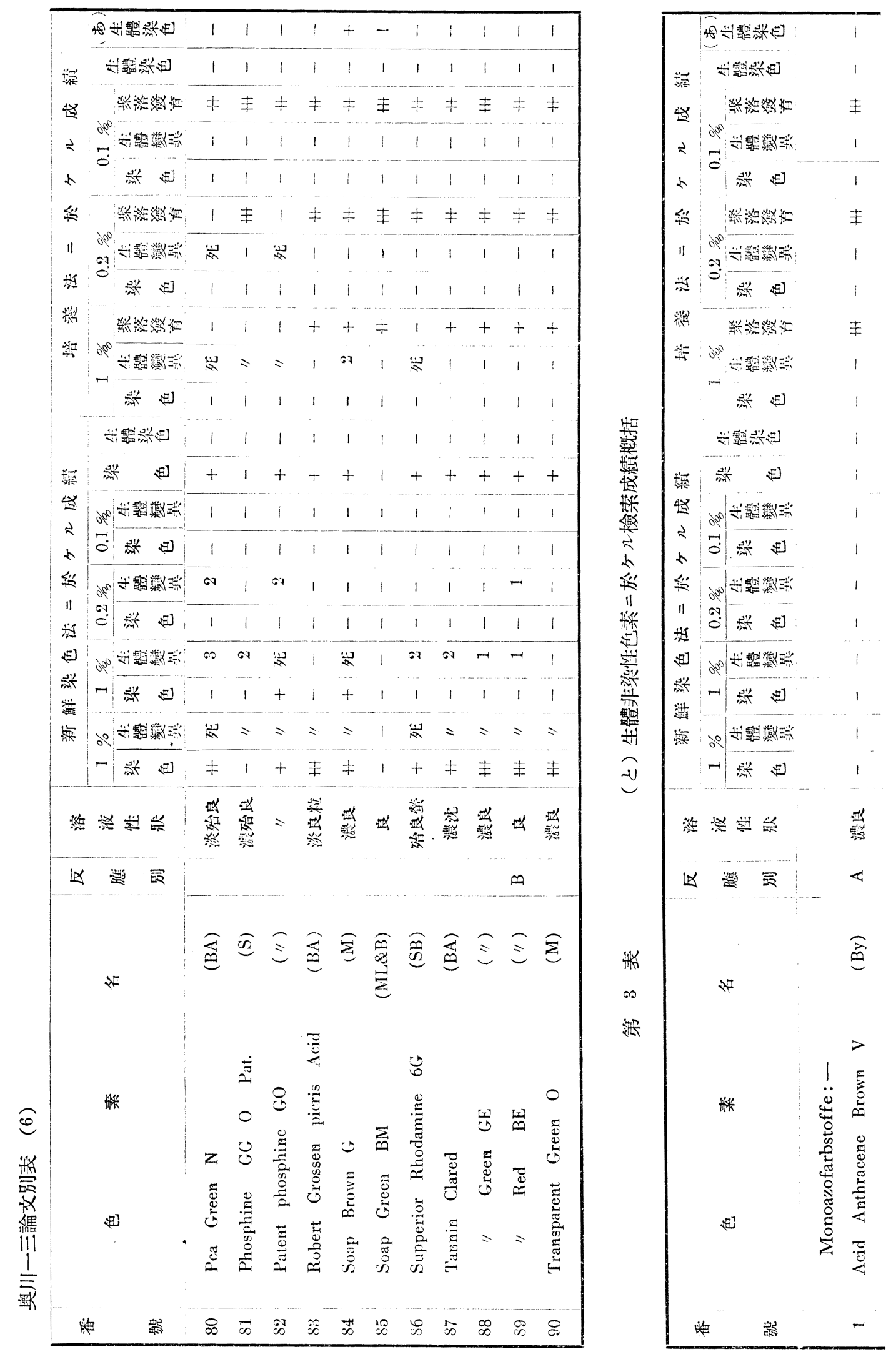


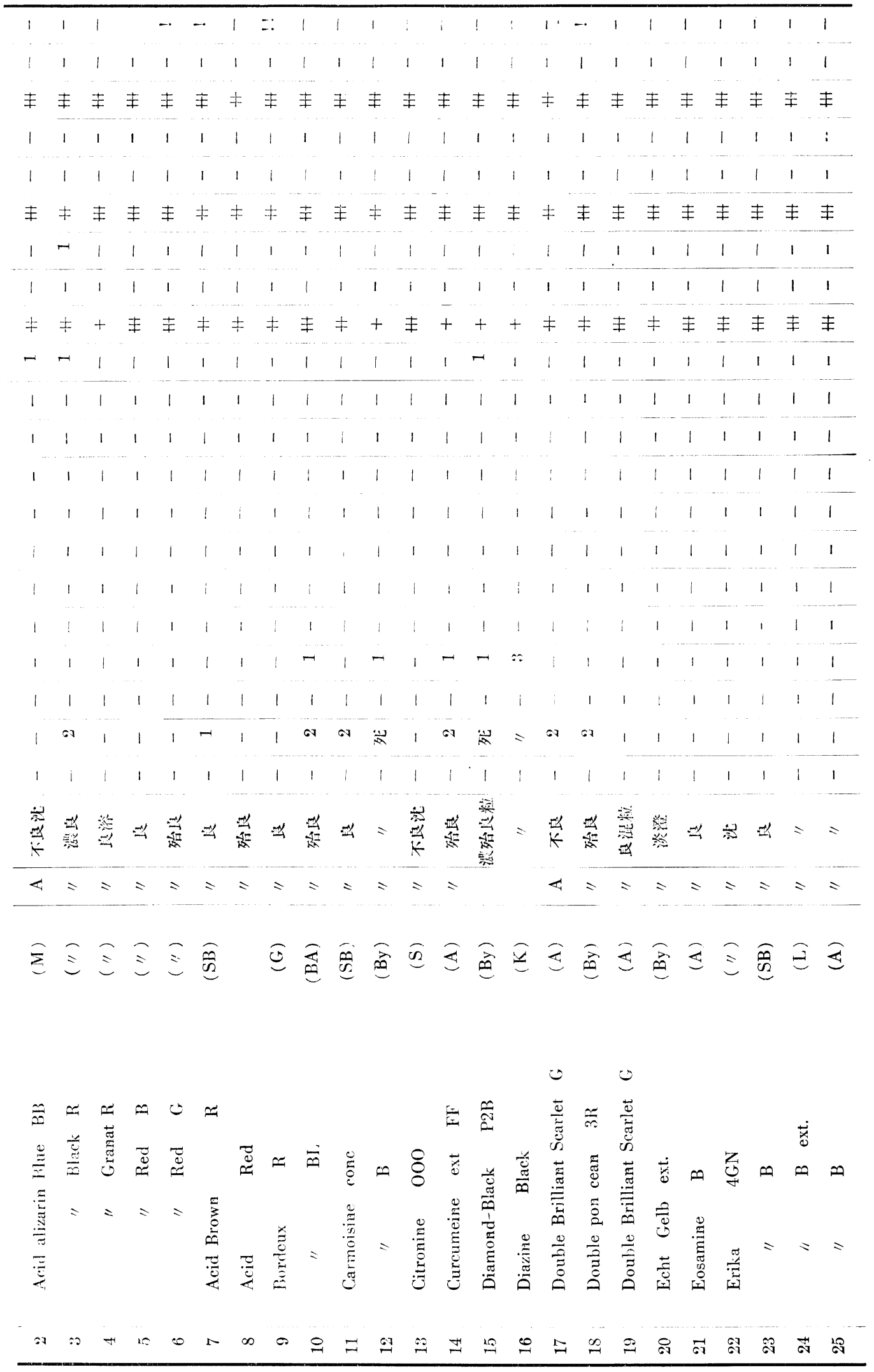




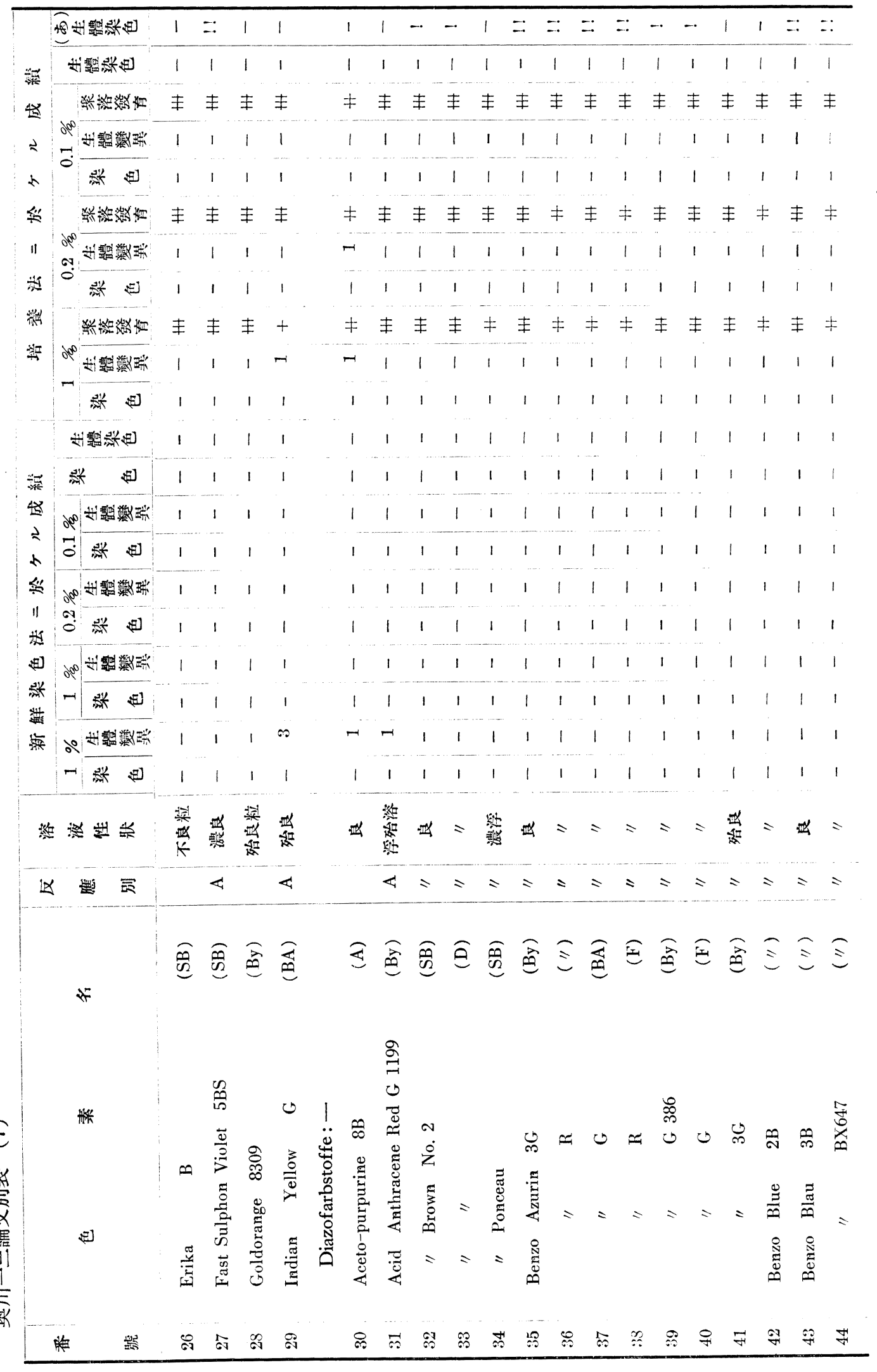




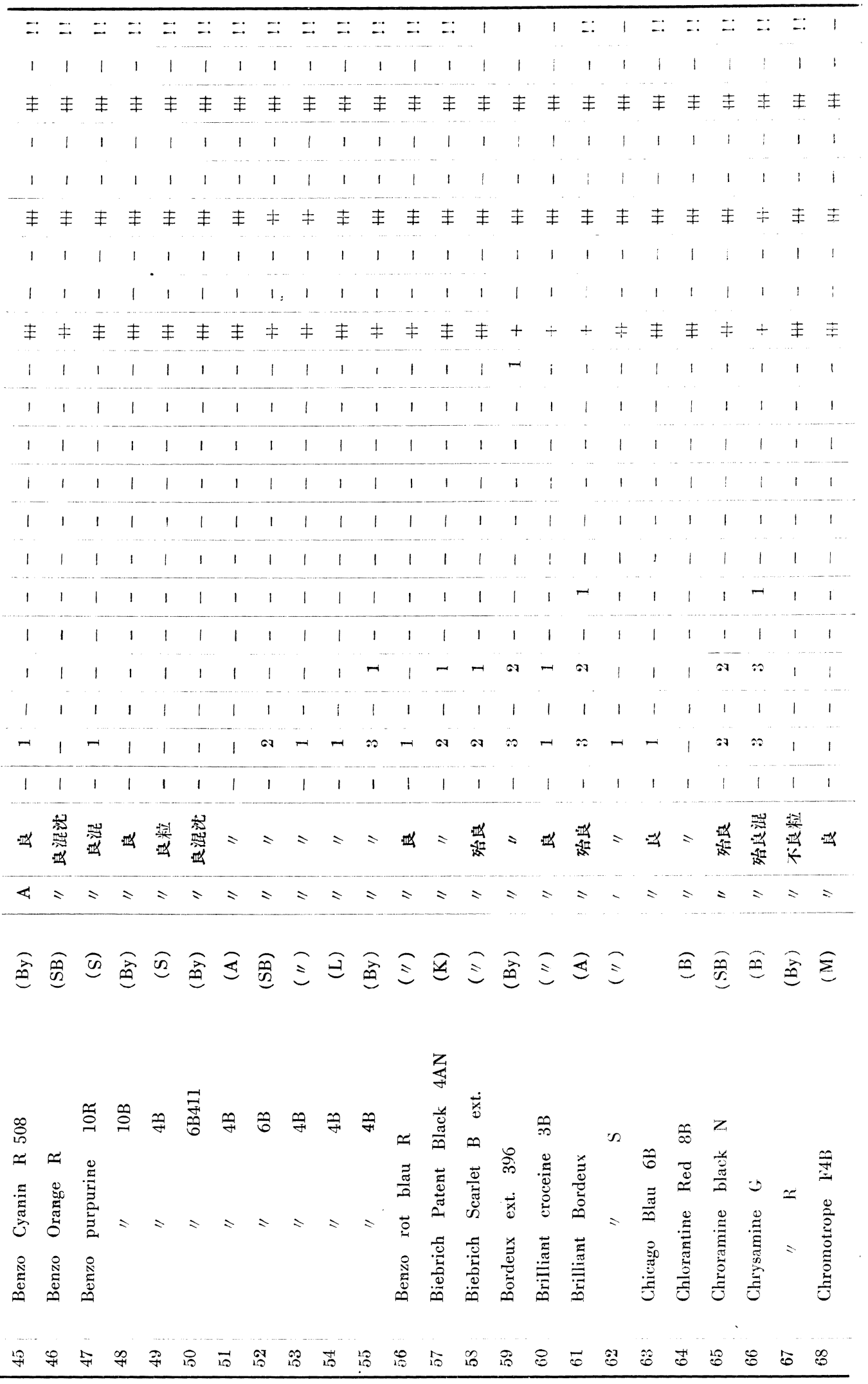




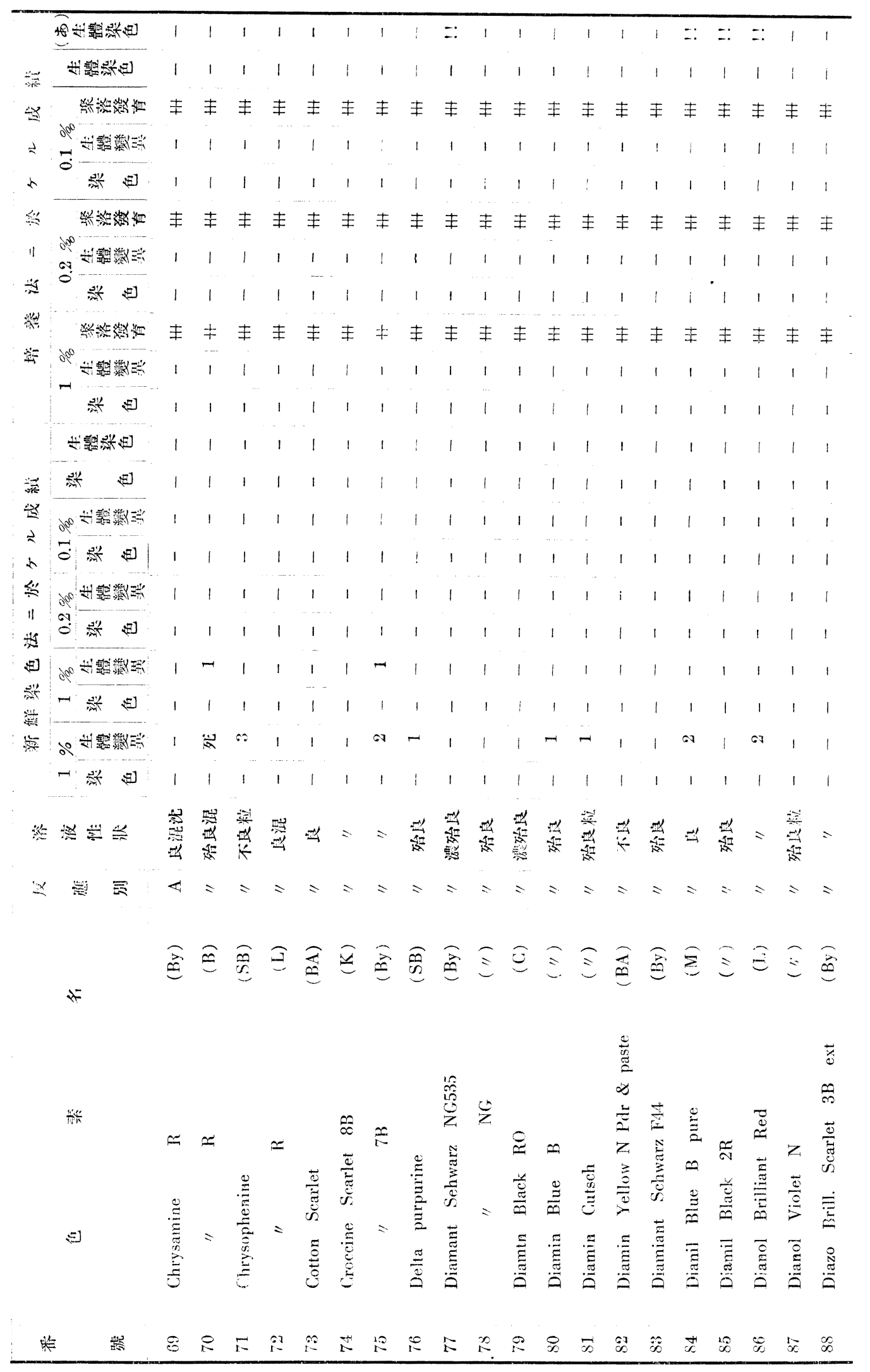




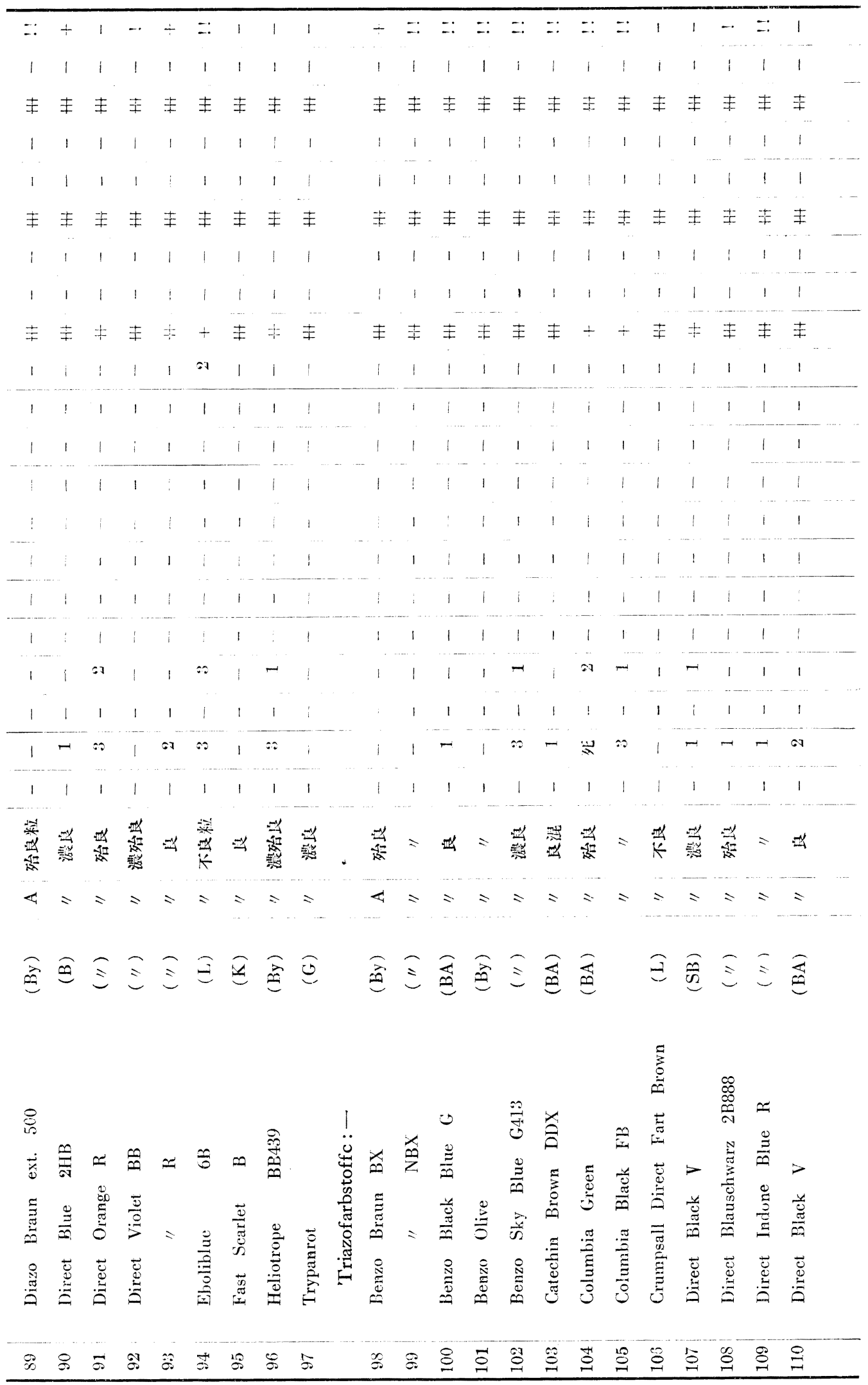




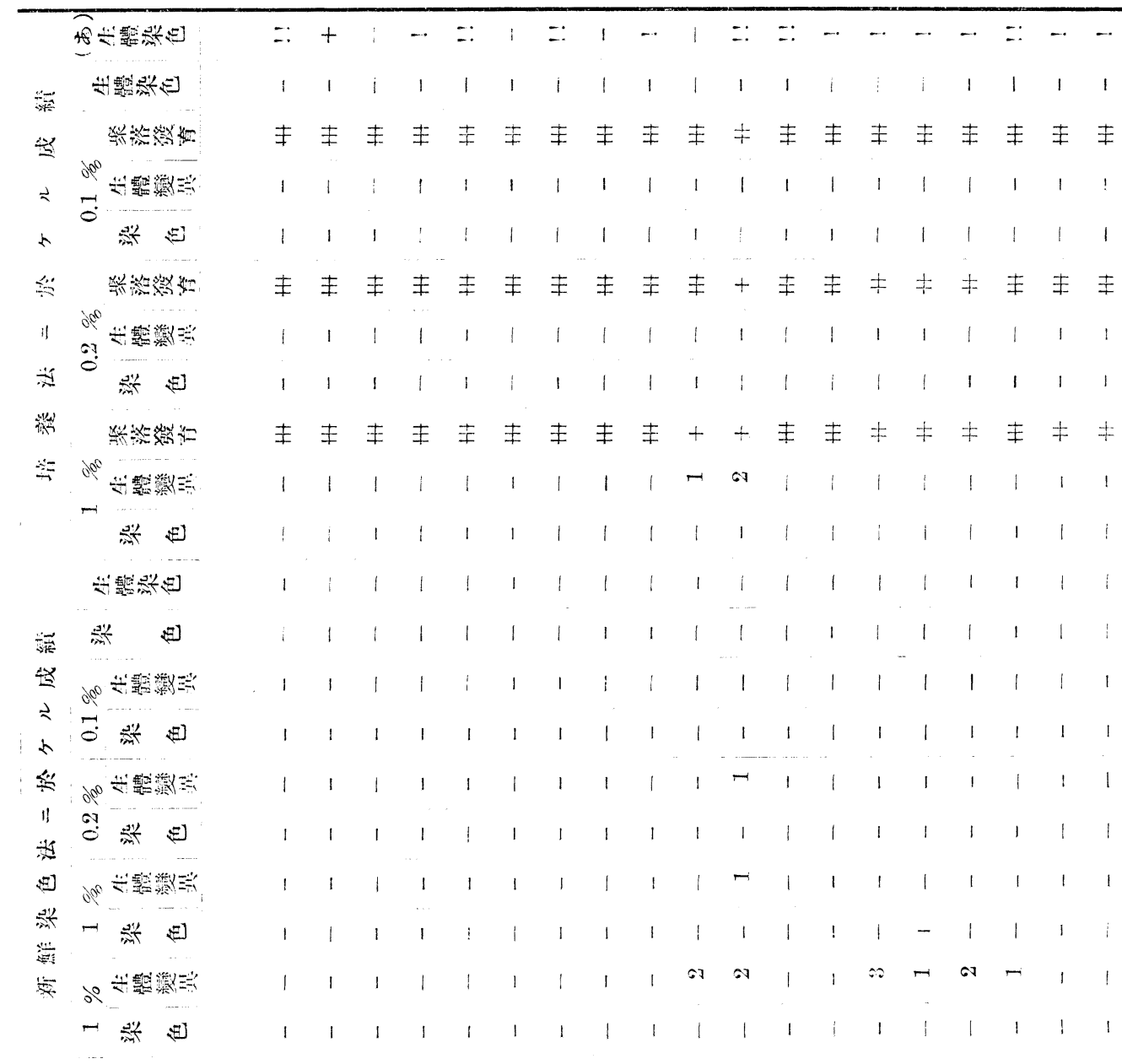

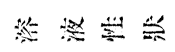

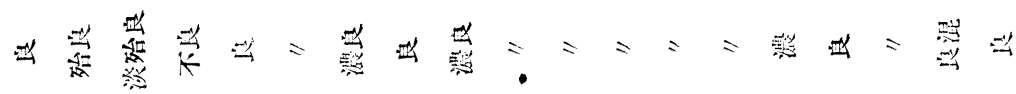
世 鼠

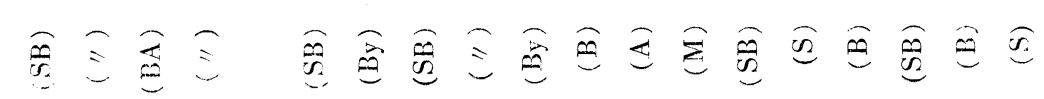

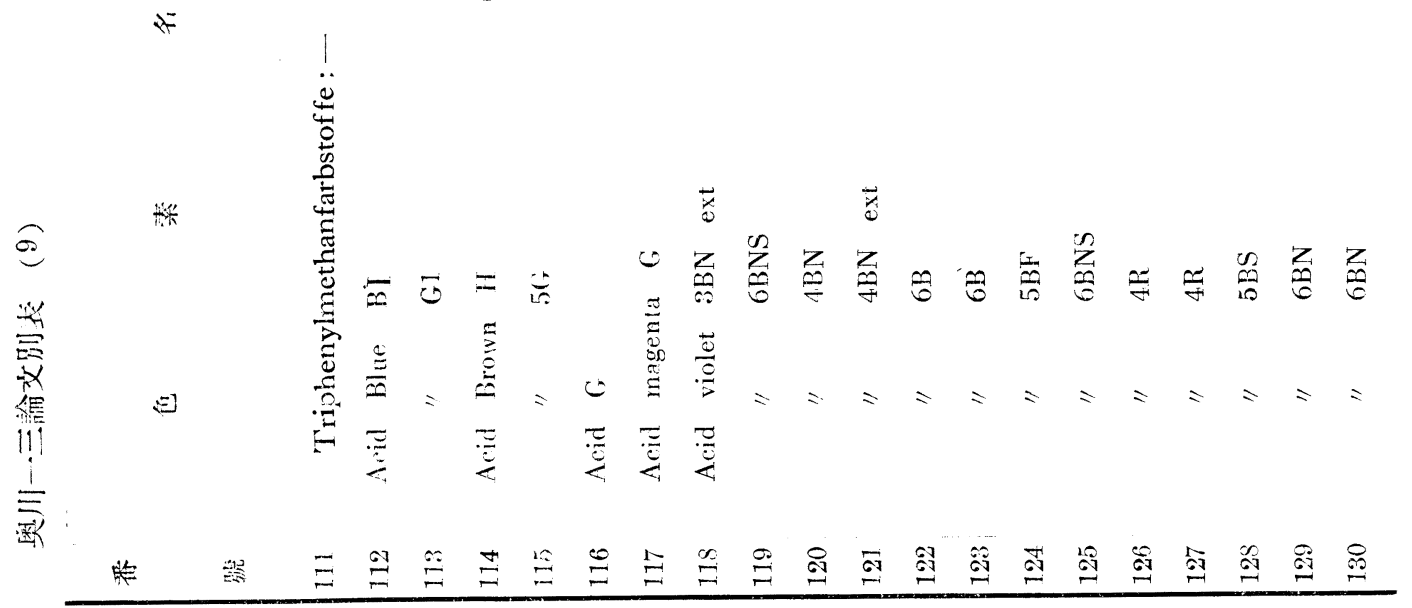




\begin{tabular}{|c|c|c|c|c|c|c|c|c|c|c|c|c|c|c|c|c|c|c|c|c|c|c|c|}
\hline$\cdots$ & 1 & 1 & $\cdots$ & 1 & $=:$ & 1 & 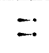 & $\cdots$ & 1 & $\because$ & 1 & $\because$ & $\because$ & & 1 & 1 & 1 & 1 & 1 & 1 & 1 & 1 & 1 \\
\hline 1 & 1 & 1 & 1 & 1 & 1 & 1 & 1 & 1 & 1 & 1 & 1 & 1 & 1 & & 1 & 1 & 1 & 1 & 1 & 1 & 1 & 1 & 1 \\
\hline 寿 & $\neq$ & 夆 & 丰 & 主 & $\neq$ & 主 & $\neq$ & 主 & 声 & 主 & 主 & $\neq$ & $\neq$ & & 䒠 & 夆 & 籴 & $\neq$ & $\neq$ & 主 & $\neq$ & 主 & 主 \\
\hline 1 & 1 & 1 & 1 & 1 & 1 & 1 & 1 & 1 & 1 & 1 & 1 & 1 & 1 & & 1 & 1 & 1 & 1 & 1 & 1 & 1 & 1 & 1 \\
\hline 1 & 1 & 1 & 1 & 1 & 1 & 1 & 1 & 1 & 1 & 1 & 1 & 1 & 1 & & 1 & 1 & 1 & 1 & 1 & 1 & 1 & 1 & 1 \\
\hline 声 & + & $\neq$ & 亦 & H & $\neq$ & 寿 & 夆 & $\neq$ & $\neq$ & $\neq$ & 主 & 主 & \pm & & 主 & 主 & $\neq$ & $\neq$ & $\neq$ & $\neq$ & \pm & $\neq$ & 丰 \\
\hline 1 & $r$ & 1 & 1 & 1 & 1 & 1 & 1 & 1 & 1 & 1 & 1 & 1 & 1 & & 1 & 1 & 1 & 1 & 1 & 1 & 1 & 1 & 1 \\
\hline 1 & 1 & 1 & 1 & 1 & 1 & 1 & 1 & 1 & 1 & 1 & 1 & 1 & 1 & & 1 & 1 & 1 & 1 & 1 & 1 & 1 & 1 & 1 \\
\hline 主 & + & $\neq$ & $\neq$ & $\neq$ & $\neq$ & 专 & $\neq$ & $\neq$ & $\neq$ & $\neq$ & 丰 & 主 & \# & & + & 主 & $\neq$ & $\neq$ & + & 主 & $\neq$ & 主 & 夆 \\
\hline 1 & $r$ & 1 & 1 & 1 & 1 & 1 & 1 & 1 & 1 & 1 & 1 & 1 & 1 & & -1 & 1 & 1 & 1 & $r$ & 1 & 1 & 1 & 1 \\
\hline 1 & 1 & 1 & 1 & 1 & 1 & 1 & 1 & 1 & 1 & 1 & 1 & 1 & 1 & & 1 & 1 & 1 & 1 & 1 & 1 & 1 & 1 & 1 \\
\hline 1 & 1 & 1 & 1 & 1 & 1 & 1 & 1 & 1 & 1 & 1 & 1 & 1 & 1 & & 1 & 1 & 1 & 1 & 1 & 1 & 1 & 1 & 1 \\
\hline 1 & 1 & 1 & 1 & 1 & 1 & 1 & 1 & 1 & 1 & 1 & 1 & 1 & 1 & & 1 & 1 & 1 & 1 & 1 & 1 & 1 & 1 & 1 \\
\hline 1 & 1 & 1 & 1 & 1 & 1 & 1 & 1 & 1 & 1 & 1 & 1 & 1 & 1 & & 1 & 1 & 1 & 1 & 1 & 1 & 1 & 1 & 1 \\
\hline 1 & 1 & 1 & 1 & 1 & 1 & 1 & 1 & 1 & $i$ & 1 & 1 & 1 & 1 & & 1 & 1 & 1 & 1 & 1 & 1 & 1 & 1 & 1 \\
\hline 1 & 1 & 1 & 1 & 1 & 1 & 1 & 1 & 1 & 1 & 1 & I & 1 & 1 & & 1 & 1 & 1 & 1 & 1 & 1 & 1 & 1 & 1 \\
\hline 1 & 1 & 1 & 1 & 1 & 1 & 1 & 1 & 1 & 1 & 1 & 1 & 1 & I & & 1 & 1 & 1 & 1 & 1 & I & 1 & 1 & 1 \\
\hline 1 & $r$ & 1 & 1 & 1 & 1 & 1 & 1 & 1 & 1 & 1 & 1 & 1 & 1 & & 1 & 1 & 1 & 1 & $r$ & 1 & 1 & 1 & 1 \\
\hline 1 & 1 & 1 & 1 & 1 & 1 & 1 & 1 & 1 & 1 & 1 & 1 & 1 & 1 & & 1 & 1 & 1 & 1 & 1 & 1 & 1 & 1 & 1 \\
\hline 1 & 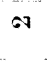 & 1 & -1 & 1 & o & 1 & 1 & 1 & or & 1 & $r$ & 1 & 1 & & 00 & 1 & 1 & 1 & 00 & 1 & -1 & 1 & 1 \\
\hline 1 & 1 & 1 & 1 & 1 & 1 & 1 & 1 & 1 & 1 & 1 & 1 & 1 & । & & 1 & 1 & 1 & 1 & 1 & 1 & 1 & 1 & 1 \\
\hline 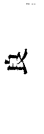 & 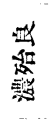 & 些 & 些 & 些 & $=0$ & 誉 & $\begin{array}{l}\text { 些 } \\
\text { 照 } \\
\text { 瑟 }\end{array}$ & 登 & $\#$ & $=$ & $\frac{5}{2}$ & 紫 & 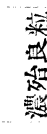 & & 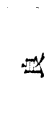 & 些 & 黛 & 此 & $=$ & $\approx$ & $=$ & $=$ & 賦 \\
\hline$\varangle$ & $=$ & $=$ & $=$ & $\infty$ & $\varangle$ & $\infty$ & $=$ & $\varangle$ & $=$ & $=$ & $=$ & $=$ & $=$ & & $\varangle$ & $=$ & $=$ & $=$ & $=$ & $=$ & $=$ & $=$ & $=$ \\
\hline 氙 & $\stackrel{x}{a}$ & 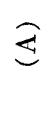 & $\widehat{0}$ & $\widehat{\Delta}$ & 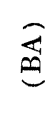 & $\hat{\theta}$ & 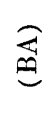 & $\widehat{0}$ & $\widehat{x}$ & 疍 & 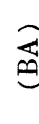 & 3 & & & 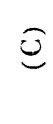 & $\Xi$ & $£$ & $\approx$ & $\widehat{\mathscr{0}}$ & $\Xi$ & $\Xi$ & $\Xi$ & 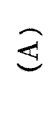 \\
\hline Z & & & & & & $\begin{array}{l}\stackrel{\dot{\omega}}{\mathrm{w}} \\
\overrightarrow{\mathrm{c}}\end{array}$ & $\frac{\mathscr{g}}{\stackrel{8}{8}}$ & & & & & & & 1 & & & $\stackrel{\dot{n}}{\stackrel{5}{0}}$ & & & & & & \\
\hline$\frac{\overline{0}}{2}$ & $\approx$ & $\infty$ & $\Leftrightarrow$ & & & $\frac{a}{0}$ & 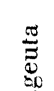 & $\stackrel{Ð}{\oplus}$ & & $\begin{array}{l}Z \\
\text { Z }\end{array}$ & 西 & $\infty$ & & 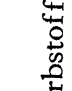 & & $\underset{\Xi}{\stackrel{Z}{\Xi}}$ & 匆 & ळ̆ & $\frac{\stackrel{0}{2}}{\frac{\pi}{N}}$ & & $\leadsto$ & & $\stackrel{\dot{m}}{\stackrel{\infty}{3}}$ \\
\hline 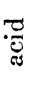 & 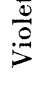 & $\stackrel{\Xi}{\Xi}$ & & & $\stackrel{\Xi}{\Xi}$ & $\begin{array}{l}\vec{E} \\
\vec{g}\end{array}$ & $\begin{array}{l}\tilde{g} \\
\stackrel{\Xi}{\Xi}\end{array}$ & 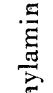 & $\begin{array}{l}\mathbb{x} \\
: \Xi\end{array}$ & D. & $\frac{0}{9}$ & ర్ & $\frac{\pi}{0}$ & 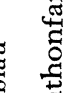 & $\begin{array}{l}1 \\
\mathscr{I}\end{array}$ & ํํㅇ & 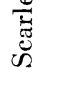 & $\dot{z}$ & $\stackrel{\varrho}{\Xi}$ & $\mathscr{\Omega}$ & $\underset{\tilde{U}}{\tilde{U}}$ & نِ & $\underset{\vec{x}}{\tilde{u}}$ \\
\hline 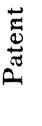 & 䇋 & 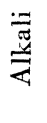 & $=$ & 葛 & 苞 & 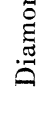 & $\stackrel{\mathscr{g}}{\mathscr{G}}$ & $\frac{\mathscr{E}}{\stackrel{0}{0}}$ & 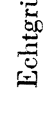 & 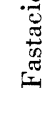 & ह્ّ & ש & שֶ & $\underset{\mathscr{N}}{\tilde{A}}$ & 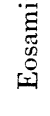 & $\underset{\substack{0 \\
0}}{0}$ & $=$ & $=$ & $=$ & $=$ & $=$ & $=$ & $=$ \\
\hline $\bar{\Xi}$ & $\stackrel{80}{0}$ & 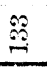 & $\stackrel{\vec{g}}{=}$ & $\stackrel{10}{9}$ & 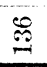 & 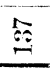 & $\begin{array}{l}\infty \\
: 2 \\
\end{array}$ & $\stackrel{9}{:}$ & 异 & $\exists$ & $\stackrel{g}{ \pm}$ & $\stackrel{\leftrightarrow}{\exists}$ & $\exists$ & & $\underset{z}{2}$ & $\stackrel{\text { 证 }}{ }$ & 声 & $\stackrel{\infty}{\sharp}$ & $\stackrel{\odot}{ \pm}$ & 8 & $\sqrt{2}$ & 照 & 19 \\
\hline
\end{tabular}




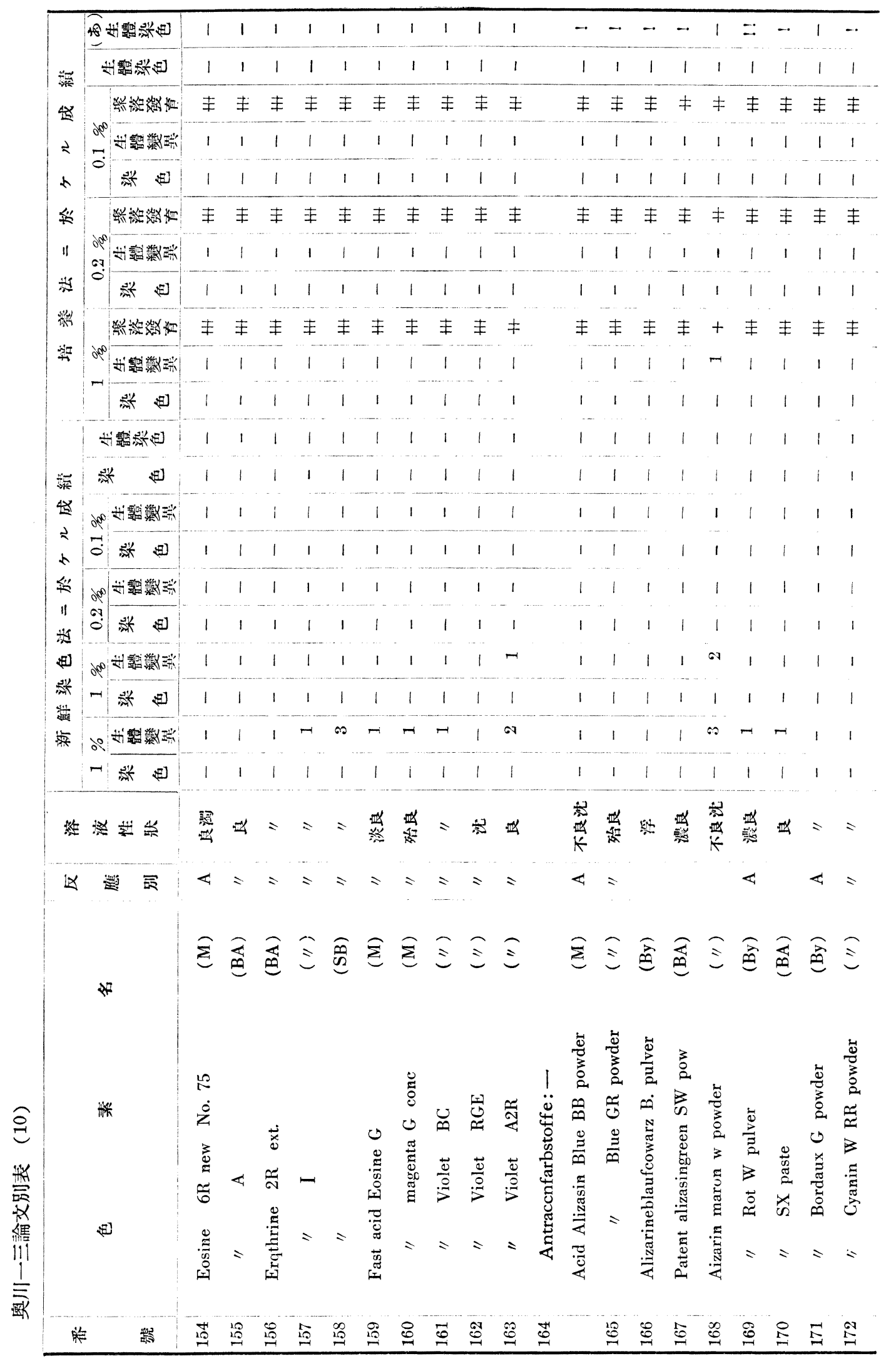




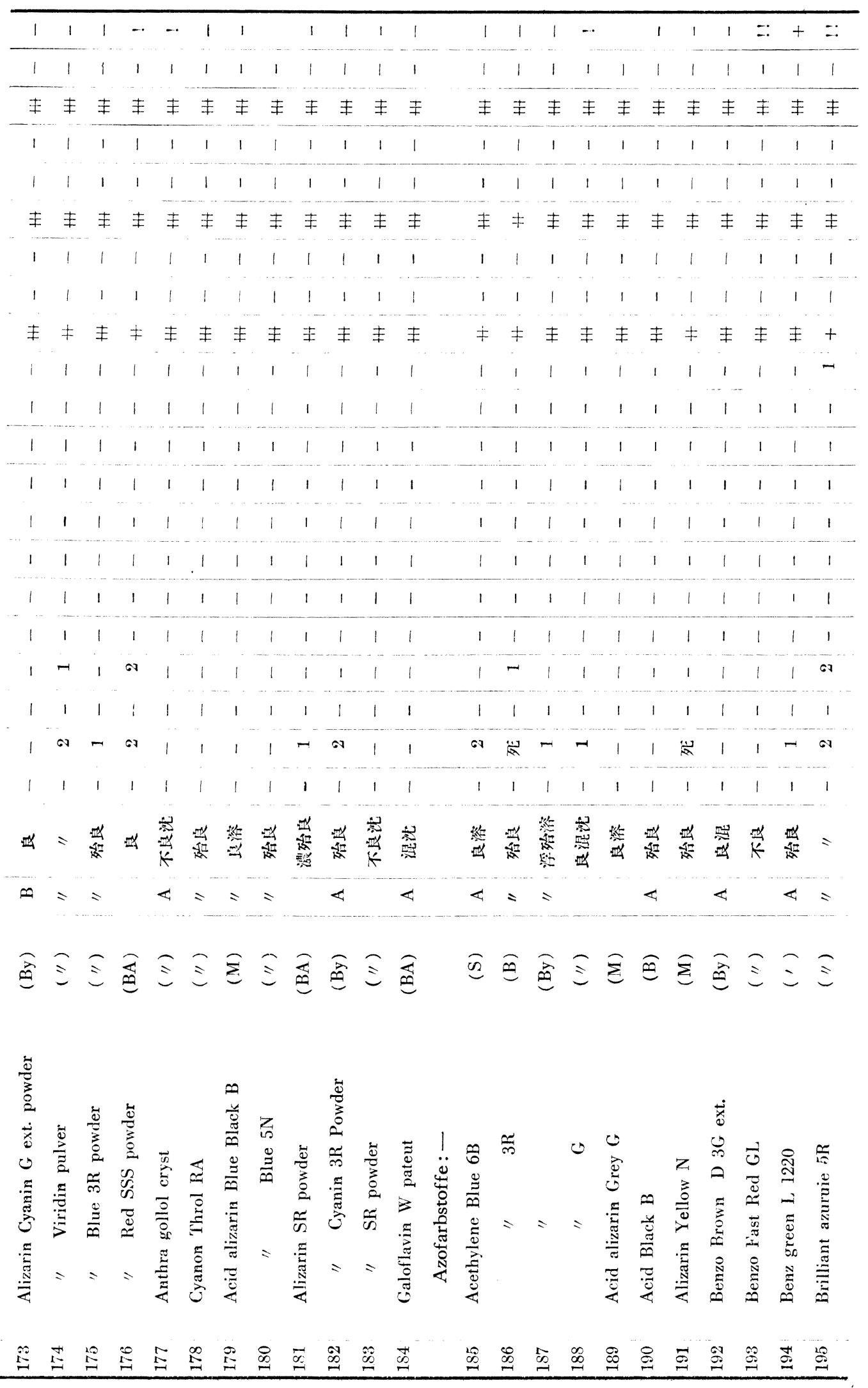




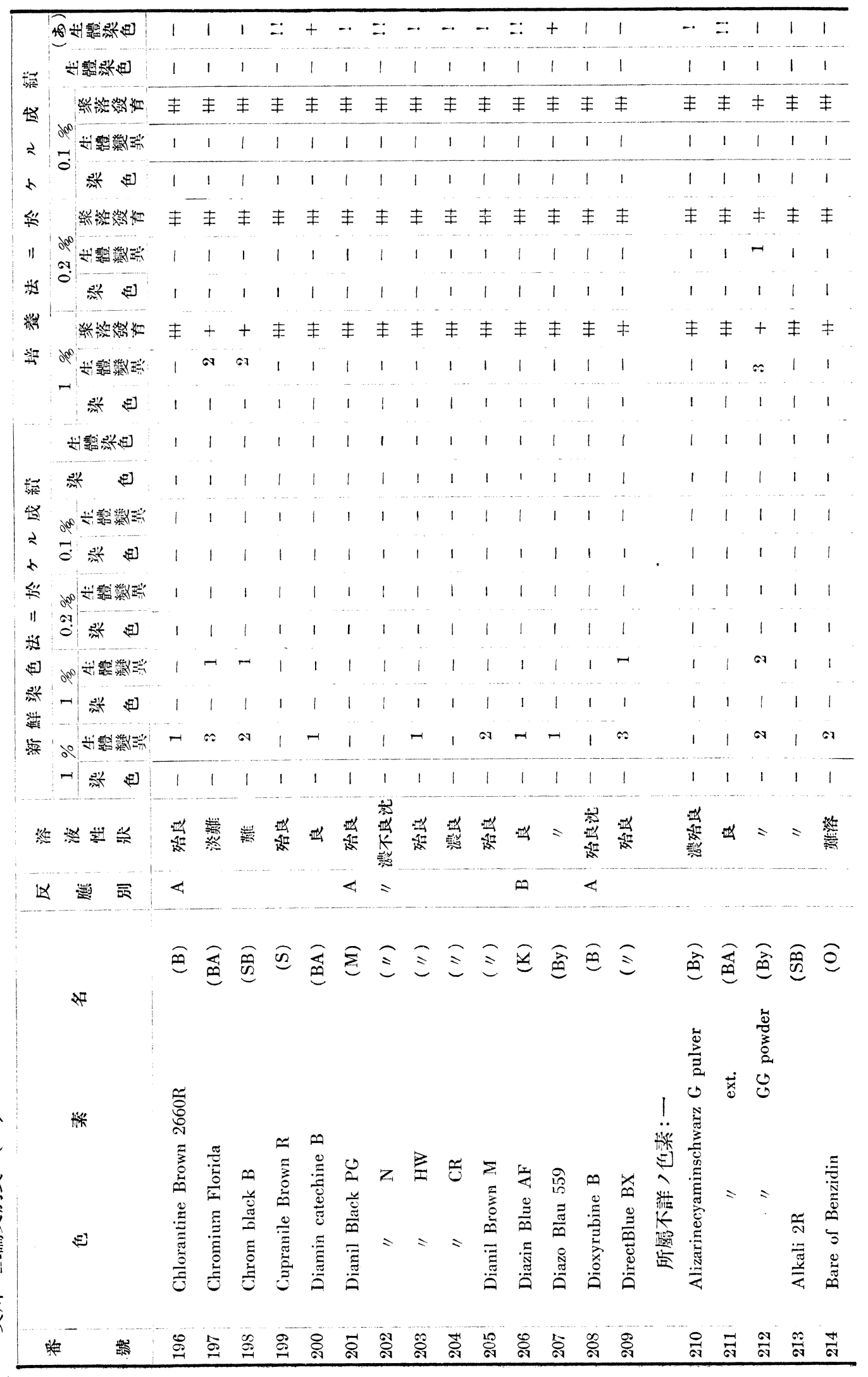




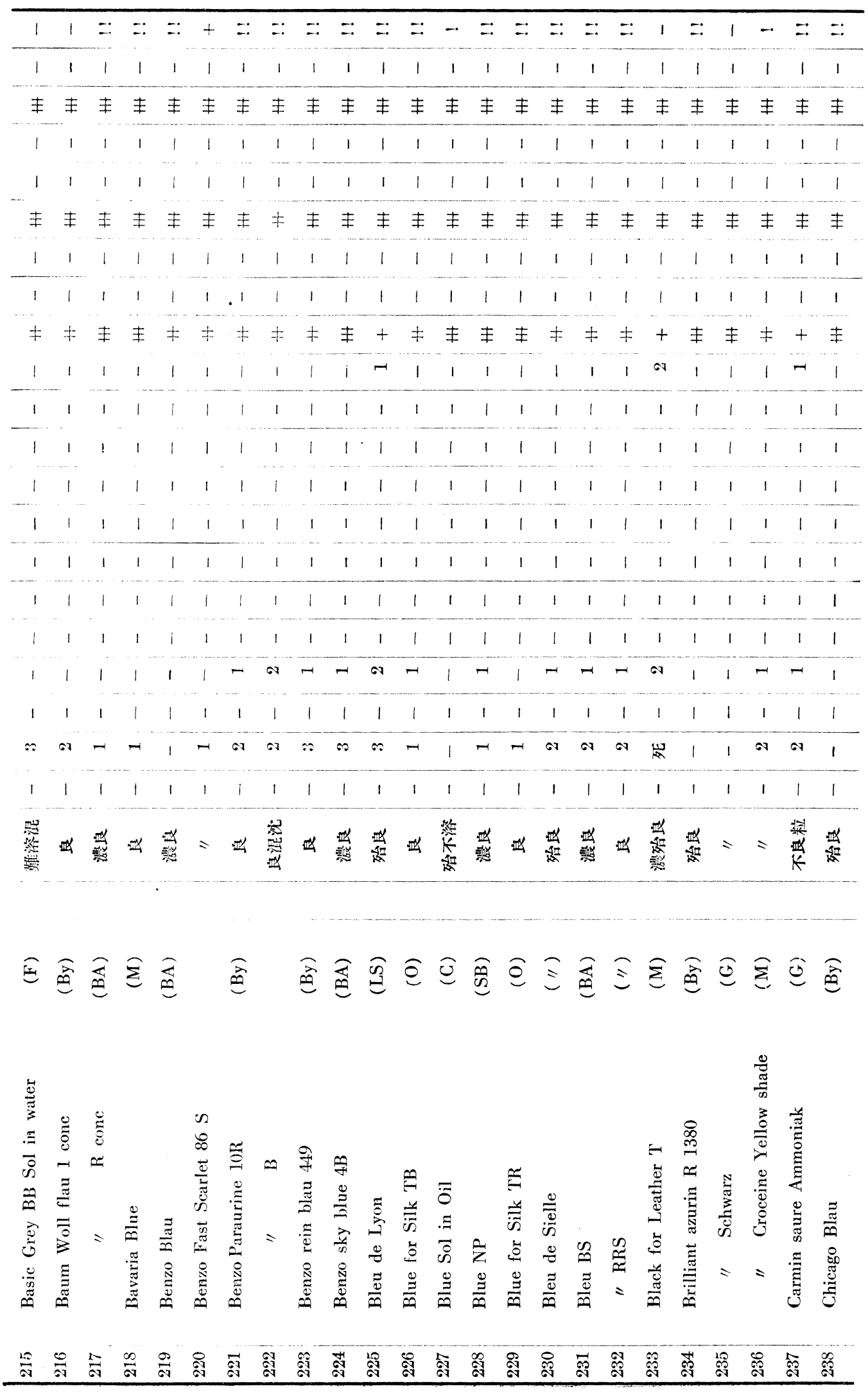




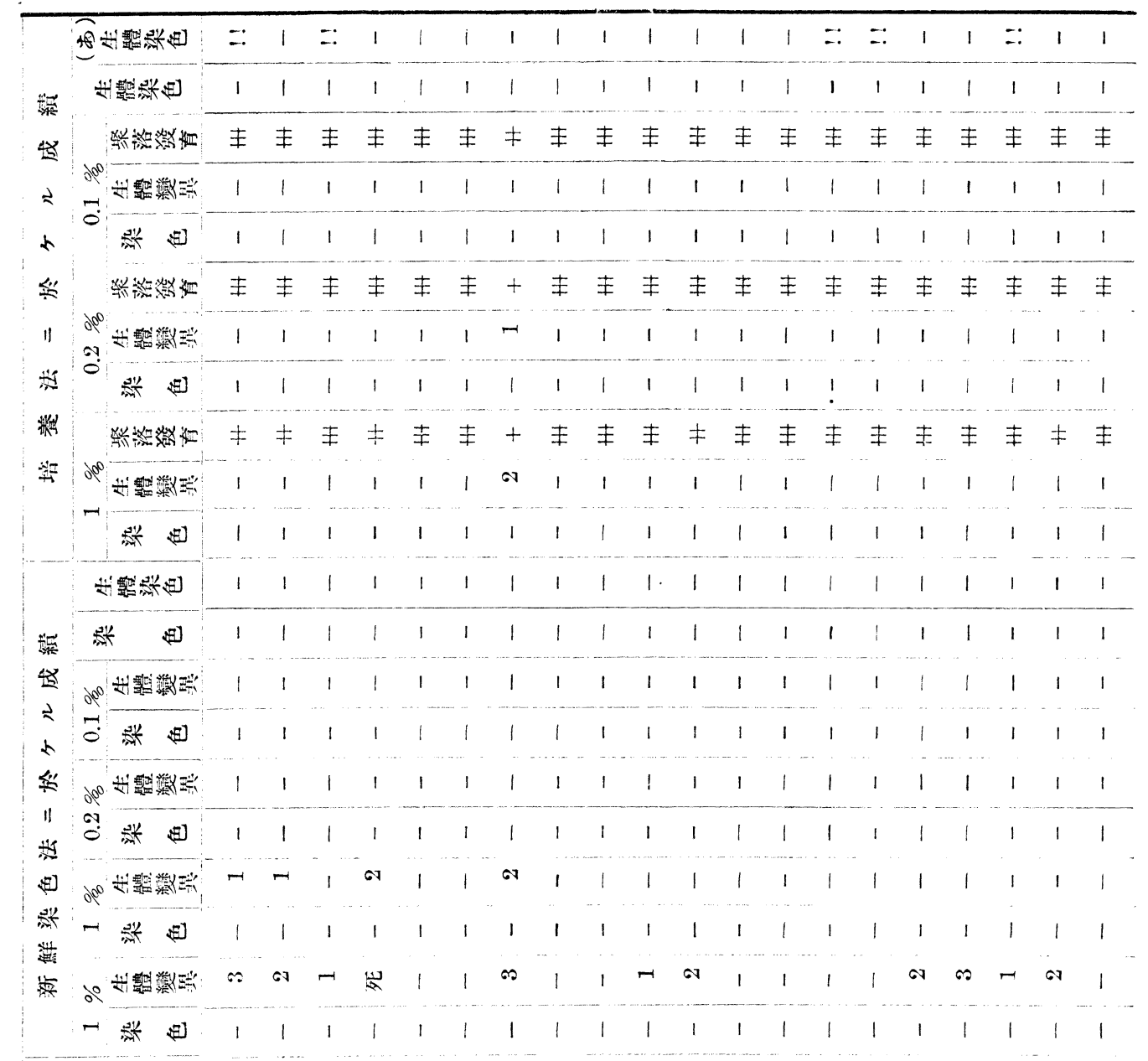

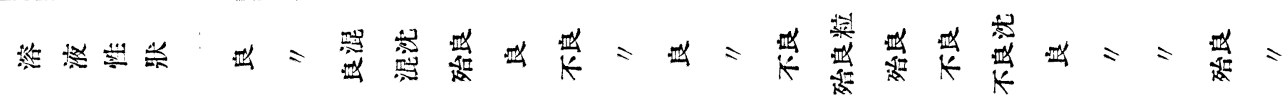
凶 宊

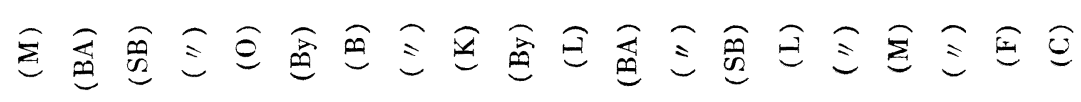

स

令

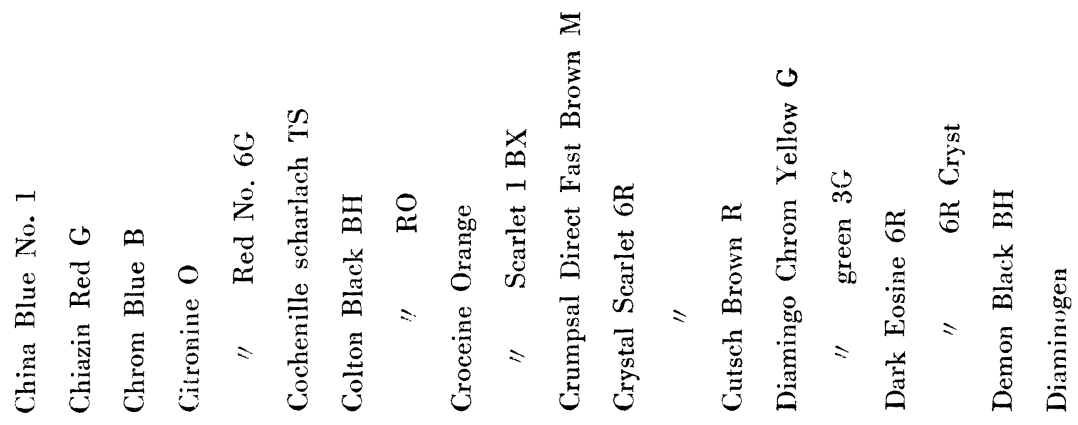

巴]

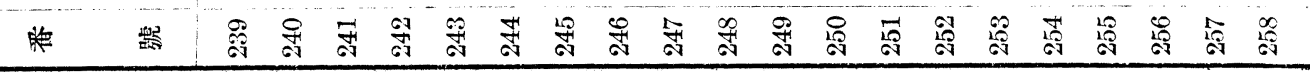




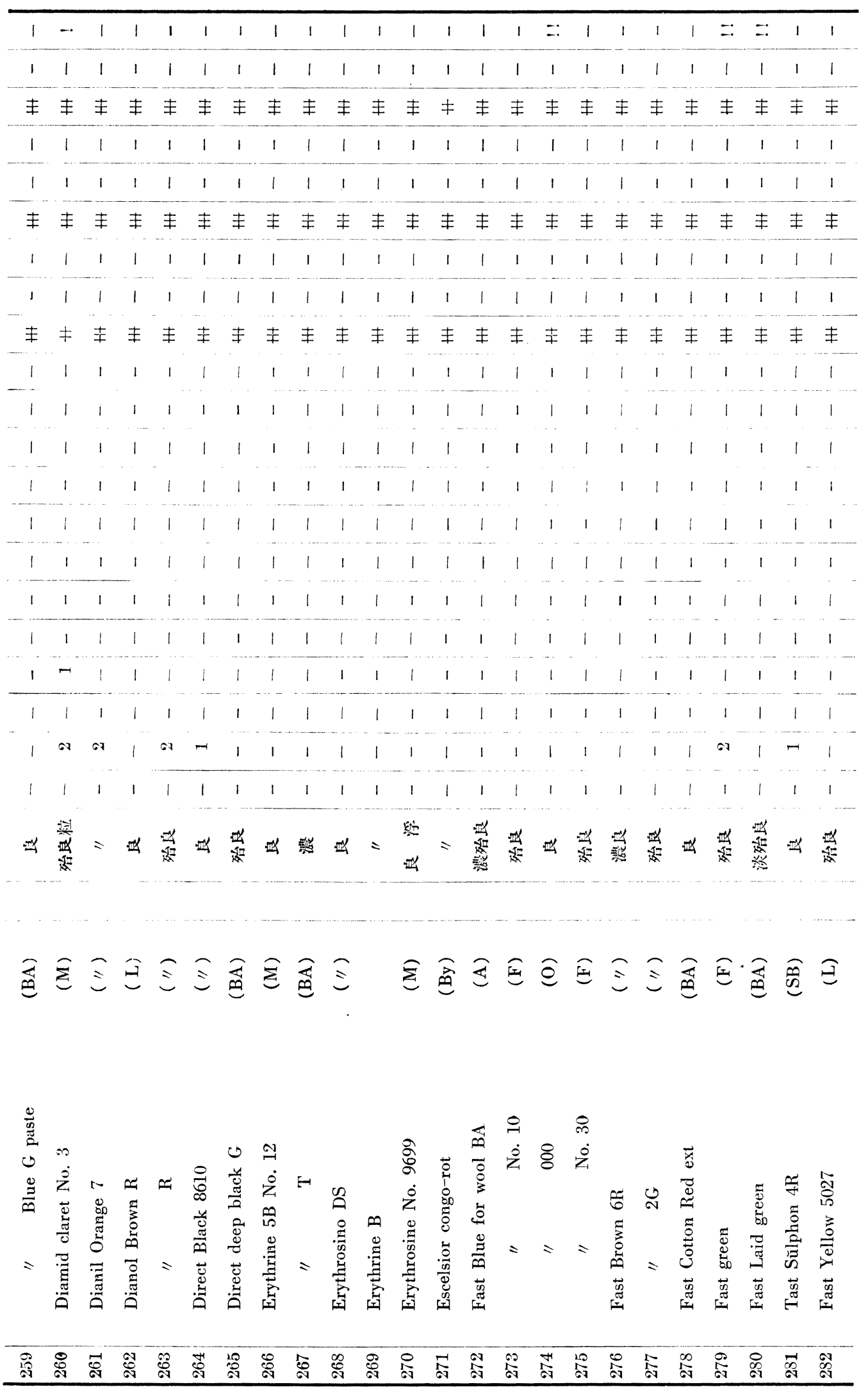




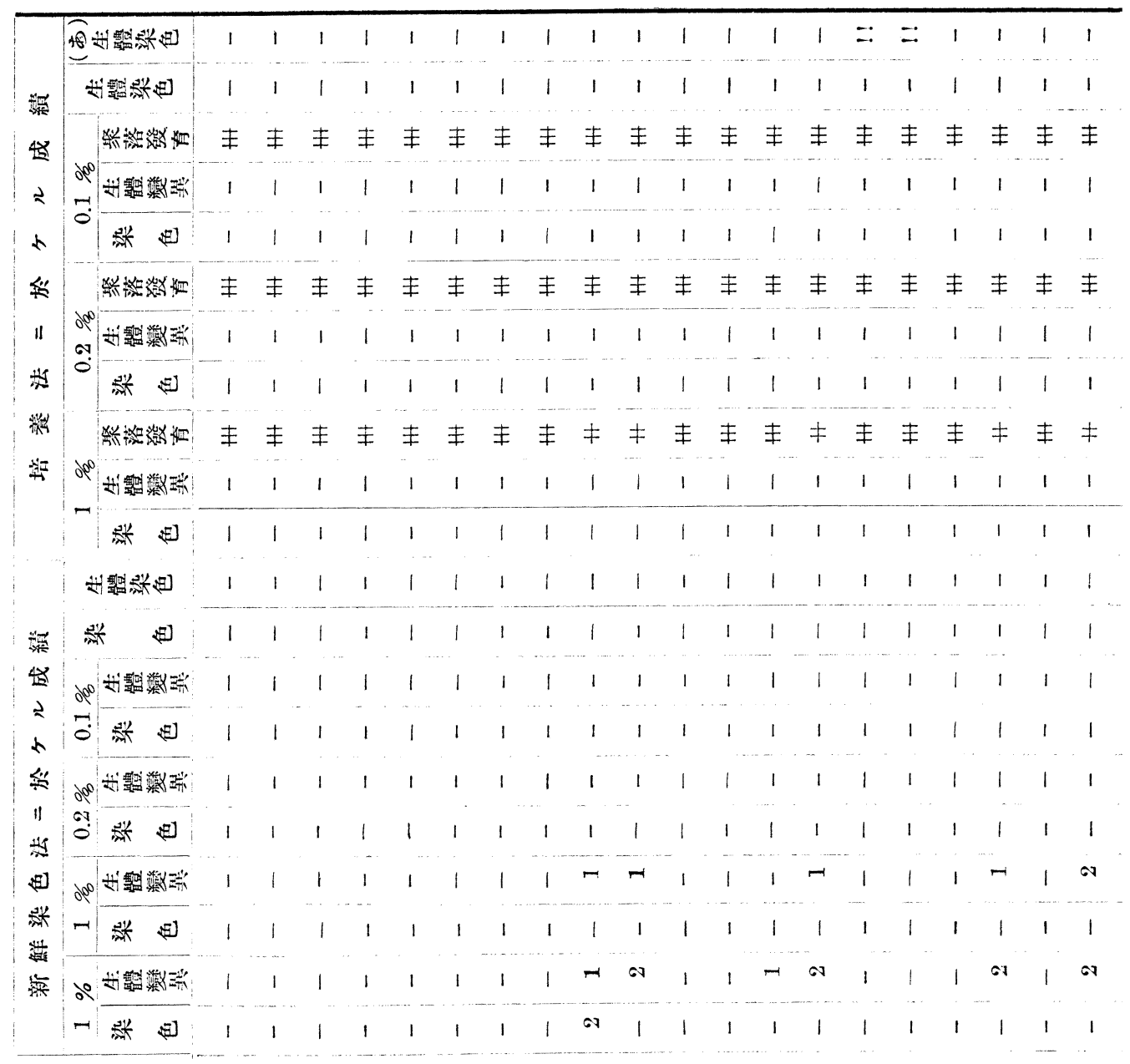

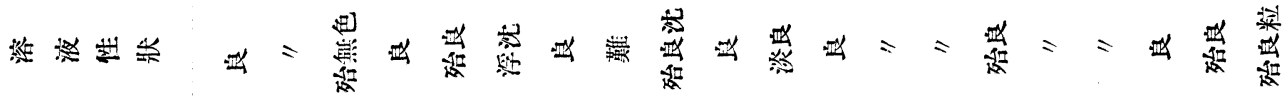
区 齿

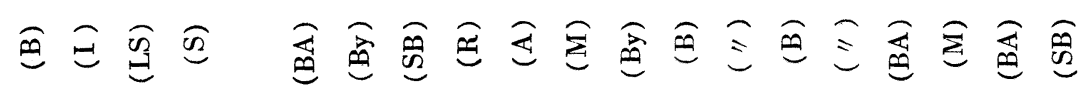

\&F

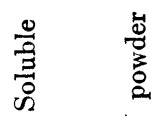

管

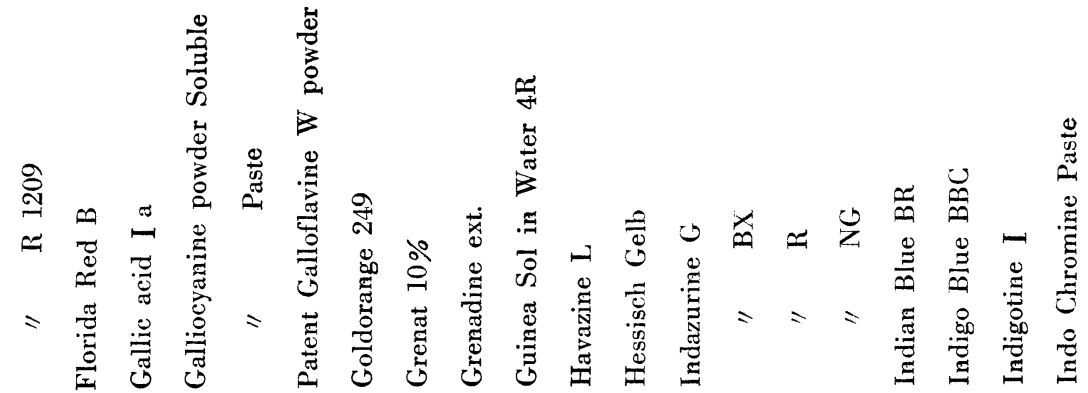

$\notin$

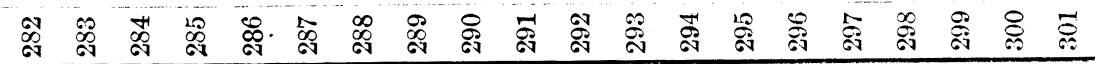




\begin{tabular}{|c|c|c|c|c|c|c|c|c|c|c|c|c|c|c|c|c|c|c|c|c|c|c|}
\hline$\because$ & 1 & 1 & 1 & 1 & & 1 & $\cdots$ & $\because$ & 1 & 1 & 1 & 1 & 1 & - & 1 & $\because:$ & - & 1 & 1 & 1 & 1 & 1 \\
\hline 1 & 1 & 1 & 1 & 1 & I & 1 & ! & 1 & I & 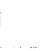 & 1 & 1 & 1 & 1 & : & 1 & 1 & 1 & 1 & 1 & 1 & 1 \\
\hline 丰 & 丰 & 丰 & 丰 & 丰 & 主 & 末 & 籴 & 丰 & 丰 & $F$ & 丰 & $\neq$ & $\neq$ & 丰 & 夆 & 圭 & 表 & 夆 & 丰 & 丰 & 主 & 丰 \\
\hline 1 & 1 & 1 & 1 & 1 & i & 1 & ! & 1 & I & 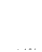 & 1 & 1 & 1 & 1 & 1 & 1 & 1 & $i$ & 1 & 1 & 1 & 1 \\
\hline & 1 & 1 & 1 & 1 & 1 & 1 & 1 & 1 & 1 & & 1 & 1 & 1 & 1 & 1 & 1 & 1 & 1 & 1 & 1 & 1 & 1 \\
\hline 主 & 末 & $\mp$ & 平 & \pm & 丰 & $\neq$ & $\neq$ & 丰 & \# & & 丰 & 丰 & 丰 & 寿 & 主 & 主 & 寿 & 主 & 寿 & 表 & $\neq$ & 主 \\
\hline 1 & 1 & 1 & 1 & 1 & 1 & & ! & ! & 1 & & 1 & 1 & 1 & 1 & 1 & 1 & 1 & 1 & $i$ & 1 & 1 & 1 \\
\hline 1 & & 1 & 1 & 1 & 1 & 1 & 1 & 1 & & & 1 & 1 & 1 & 1 & 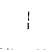 & 1 & 1 & 1 & 1 & ! & 1 & 1 \\
\hline$\ddagger$ & 寿 & 籴 & 主 & 专 & 主 & $\neq$ & $\neq$ & キ & $\exists$ & & 寿 & 丰 & $\neq$ & 丰 & $\neq$ & 丰 & 羊 & $\neq$ & $\neq$ & $\neq$ & $\neq$ & 专 \\
\hline$i$ & & 1 & 1 & 1 & 1 & 1 & 1 & 1 & 1 & 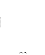 & 1 & 1 & 1 & 1 & 1 & 1 & 1 & 1 & 1 & 1 & 1 & 1 \\
\hline : & 1 & & 1 & 1 & 1 & 1 & 1 & 1 & 1 & & 1 & 1 & 1 & 1 & 1 & 1 & 1 & 1 & 1 & 1 & 1 & 1 \\
\hline & 1 & 1 & $!$ & 1 & ' & 1 & 1 & 1 & 1 & & 1 & 1 & 1 & 1 & 1 & 1 & 1 & & 1 & & 1 & 1 \\
\hline 1 & & 1 & 1 & & 1 & 1 & 1 & 1 & 1 & 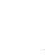 & 1 & $!$ & 1 & 1 & 1 & 1 & 1 & 1 & & 1 & 1 & I \\
\hline & & 1 & 1 & 1 & 1 & 1 & 1 & 1 & 1 & 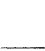 & 1 & 1 & 1 & 1 & 1 & 1 & 1 & 1 & 1 & 1 & 1 & 1 \\
\hline : & $!$ & $!$ & 1 & 1 & $!$ & 1 & 1 & 1 & 1 & - & 1 & 1 & 1 & 1 & 1 & 1 & 1 & 1 & 1 & 1 & 1 & 1 \\
\hline 1 & 1 & i & 1 & 1 & 1 & 1 & - & 1 & 1 & & 1 & 1 & 1 & 1 & 1 & 1 & 1 & 1 & 1 & 1 & $\neg$ & 1 \\
\hline 1 & 1 & 1 & 1 & 1 & 1 & 1 & 1 & 1 & 1 & . & 1 & 1 & 1 & 1 & 1 & 1 & 1 & 1 & 1 & 1 & 1 & 1 \\
\hline- & 1 & 1 & & 1 & ! & - & 07 & -1 & 1 & & 1 & 1 & $\pi$ & 1 & or & 1 & 1 & os & or & - & 67 & 1 \\
\hline$i$ & 1 & 1 & 1 & 1 & 1 & 1 & 1 & 1 & I & & 1 & 1 & 1 & 1 & 1 & 1 & 1 & 1 & 1 & 1 & 1 & 1 \\
\hline SI & 1 & - & & 1 & 1 & 07 & 00 & G & 1 & & 1 & 1 & $\omega$ & 1 & or & - & 1 & a & $a r$ & 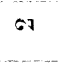 & 09 & 1 \\
\hline & & 1 & 1 & 1 & 1 & 1 & 1 & 1 & 1 & & 1 & 1 & 1 & 1 & 1 & 1 & 1 & 1 & 1 & 1 & 1 & 1 \\
\hline 萦 & $=$ & 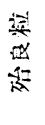 & $\approx$ & 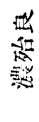 & $=$ & 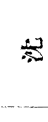 & 咄 & 蓄 & 蓓 & & 整 & 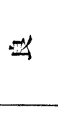 & 苪 & 紫 & 些 & 空 & 诎 & 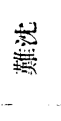 & 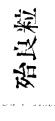 & 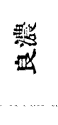 & 패 & 留 \\
\hline$\cong$ & $\equiv$ & & $\bar{\xi}$ & 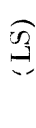 & 3 & 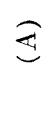 & $\widehat{\theta}$ & ج্ & 苗 & & $\Xi$ & 孚 & $\widehat{\Sigma}$ & $\sqrt{2}$ & $\Xi$ & $\widehat{્}$ & $\S$ & $\bar{E}$ & $\widehat{\vartheta}$ & $£$ & $\vec{d}$ & 5 \\
\hline 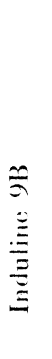 & 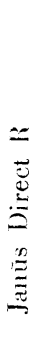 & 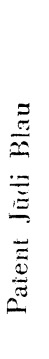 & 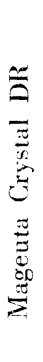 & 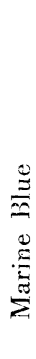 & 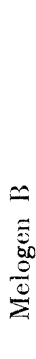 & 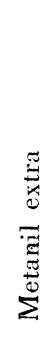 & 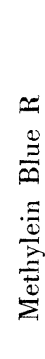 & 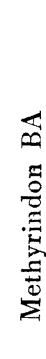 & 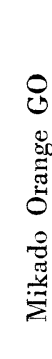 & 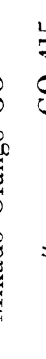 & 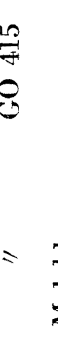 & $\begin{array}{l}\stackrel{9}{\Xi} \\
\frac{0}{0} \\
\frac{1}{2}\end{array}$ & 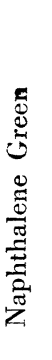 & 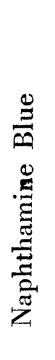 & 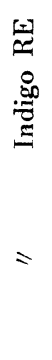 & $\begin{array}{l}\frac{3}{0} \\
\stackrel{0}{D} \\
2 \\
z \\
z \\
z\end{array}$ & 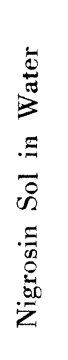 & 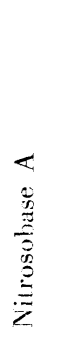 & 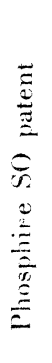 & 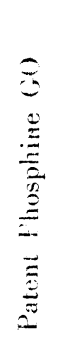 & 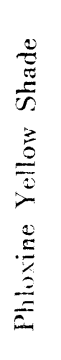 & 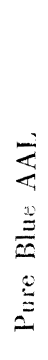 \\
\hline$\stackrel{3}{\because}$ & 吢 & 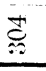 & 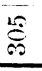 & $\stackrel{8}{:}$ & $\therefore$ & $\stackrel{2}{2}$ & $\approx$ & $\infty$ & $\Leftrightarrow$ & & 5 & $\stackrel{\leftrightarrow}{\leftrightarrow}$ & $\frac{\pi}{60}$ & $\frac{12}{30}$ & $\stackrel{0}{0}$ & 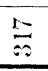 & $\frac{\infty}{\infty}$ & $\Xi$ & : & 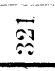 & 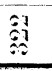 & \\
\hline
\end{tabular}

